\title{
Article \\ Study on Air-to-Water Heat Pumps Seasonal Performances for Heating in Greece
}

\author{
Georgios A. Mouzeviris * and Konstantinos T. Papakostas *
}

check for updates

Citation: Mouzeviris, G.A.; Papakostas, K.T. Study on Air-to-Water Heat Pumps Seasonal Performances for Heating in Greece. Energies 2022, 15, 279. https:// doi.org/10.3390/en15010279

Academic Editor: Alessandro Cannavale

Received: 6 October 2021 Accepted: 2 November 2021 Published: 1 January 2022

Publisher's Note: MDPI stays neutral with regard to jurisdictional claims in published maps and institutional affiliations.

Copyright: (C) 2022 by the authors. Licensee MDPI, Basel, Switzerland. This article is an open access article distributed under the terms and conditions of the Creative Commons Attribution (CC BY) license (https:/ / creativecommons.org/licenses/by/ $4.0 /)$.
Process Equipment Design Laboratory, School of Mechanical Engineering, Faculty of Engineering, Aristotle University of Thessaloniki, 54124 Thessaloniki, Greece

* Correspondence: gmouzeviris@gmail.com (G.A.M.); kpapakos@auth.gr (K.T.P.)

\begin{abstract}
Air-to-water heat pumps (AWHPs) is a very good option for efficient heating in the residential and commercial building sectors. Their performance and therefore the use of primary energy and $\mathrm{CO}_{2}$ gas emissions are affected by various factors. The aim of this paper is to present a study on the seasonal coefficient of performance in heating (SCOP) of AWHPs, which are available in the Greek market. The sample consists of 100 models in total, offered by 12 manufacturers, in a range of heat pump's thermal capacity up to $50 \mathrm{~kW}$. The calculation of SCOP values was performed according to the methodology proposed by the EN14825 standard. The results indicate how the heating capacity, the local climate, the supply water temperature, the compressor's technology, and the control system affect the seasonal performance of the various AWHP models examined. Setting the SCOP $\geq 3$ value as a criterion, the analysis that was carried out in four climatic zones A, B, C, and $\mathrm{D}$ of Greece, shows that there are many models that meet this criterion, and, in fact, their number increases from the coldest to warmer climates, in combination with lower water supply temperatures to the heating system and a control system with weather compensation.
\end{abstract}

Keywords: heat-pumps; heating systems; seasonal coefficient of performance; energy conservation; european standard EN14825

\section{Introduction}

As the 21st century unfolds, government policies around the world are increasingly focused on tackling climate change and reducing $\mathrm{CO}_{2}$ emissions. In the European Union (EU), energy policy priorities in the last years have been the lower dependence on fossil fuels and consequently the reduction of their combustion emissions, the improvement in energy efficiency, and the sustainability in energy utilization with increasing participation of renewable energy sources (RES) in final energy consumption. One of the most important energy consumers and main contributors to greenhouse gas (GHG) emissions is the building sector. In 2018, the EU's building sector was responsible for about $40.8 \%$ of total final energy consumption [1]. In the same year, space heating and domestic hot water production in residential buildings accounted for $63.6 \%$ and $14.8 \%$ of total energy consumption, respectively [2]. Additionally, in 2019, the building sector in Greece accounted for 40.6\% of the final energy consumption $(26.7 \%$ and $13.9 \%$ for residential buildings and tertiary sector, respectively) [1]. Many studies have shown that the building sector offers great potential for energy savings. The construction and renovation of buildings with advanced design techniques and the use of appropriate materials, the energy upgrade of heating and cooling systems, and the expansion of the use of renewable energy technologies are measures that can minimize energy consumption, improve energy efficiency, and reduce greenhouse gas emissions.

The EU 2030 and 2050 frameworks have set ambitious goals for reducing the primary energy consumption from fossil fuels and the related $\mathrm{CO}_{2}$ emissions [3-5]. To achieve these goals, the EU has introduced a series of directives [6-11] that require a significant 
reduction in energy use in both new and old buildings and promote the integration of highefficiency heating, ventilation, and air conditioning (HVAC) technologies that use RES for their operation. In particular, Directive 2018/844 [11] aims to accelerate the energy upgrade of existing buildings, aiming for a building stock with zero carbon footprint by 2050 .

It is very likely that, at some point in the future, the electricity grid will be completely "decarbonized", and the energy used by the HVAC systems in buildings will increasingly come from RES-generated electricity, such as photovoltaic systems, wind farms, and hydroelectric power plants, while the energy generated by the fossil fuels will tend to be zero. Additionally, the expansion of the implementation of energy saving programs and energy upgrade of the buildings with economic incentives from government services and agencies, in addition to the development of the market of buildings with nearly zero-energy consumption (NZEB), will lead to continuous and large reduction of building heat losses. As building design heat loads drop, it becomes difficult (or sometimes impossible) to find gas or oil-fired boilers that would not be significantly oversized for these loads and therefore operate with reduced efficiency.

The Greek and European heating and cooling market will be affected by these trends and conditions. The increasing use of electricity will contribute to the wide use of heat pumps (HPs) and their installation in heating and cooling systems of buildings. Today, HPs are systems highly efficient, with low gas emissions given off locally, economically competitive due to their low operating costs compared to other heating systems, and their technology is mature and reliable [12] and can contribute significantly to achieving the goals of the EU. Most of the heat they provide comes from renewable sources (air, water, and soil) while with the "decarbonization" of electricity production will be considered as devices that operate exclusively with RES. In addition, HPs can use locally generated electricity in buildings.

AWHPs are heat generators that are expected to widely replace oil or gas boilers in conventional heating systems, especially in large city buildings, where the installation of ground-to-water HPs is very difficult. With the progressive reduction of the heat losses of the buildings, due to the energy upgrade, HPs offer more options in the range of heating capacities that can be combined with the lower heating loads. In general, AWHPs can operate in a wide range of outdoor temperatures, have low operating costs at low hot water temperatures, and are small in size and easily installed at relatively moderate prices. By installing thermal storage in heating and cooling systems, HPs will be able to operate in high-efficiency conditions [13] and eliminate the gap between electricity production and use by operating as thermal batteries. From the above, it appears that the market of HP is expected to grow rapidly. According to recent statistics [14], the number of air-to-water HP units sold in 2018 in Europe (EU-28) was 21.5\% higher compared to those of 2017.

The HP's efficiency is given by the coefficient of performance (COP) in heating mode and the energy efficiency ratio (EER) in cooling mode. The COP and EER coefficients represent momentary values measured under steady state operating conditions in a laboratory environment and vary according to the temperature of the heat source and sink. A detailed recording and comparison of COP and EER coefficients in relation to thermal and cooling power and temperature difference between the heat source and sink, based on the technical characteristics of 308 different air-to-water and 122 ground-to-water models available in the Greek market, is given in [5].

The HP seasonal efficiency is given by the seasonal coefficient of performance in heating mode (SCOP) and the seasonal energy efficiency ratio in cooling mode (SEER), respectively [5]. Seasonal efficiency is calculated by considering several external factors, such as the ambient air temperature, the building thermal or cooling load, the temperatures of the heating or cooling medium, and the HP's control system [4]. The impact of various factors, such as the climate, the compressor technology, and the HP over- or under-sizing in relation to the thermal load of the building and the control system, on the seasonal efficiency of the HP has been studied by various researchers abroad [13,15-20] and in Greece $[4,21]$. Francesco Madonna and Francesca Bazzocchi [15] presented a model simulating the hourly 
efficiency of reversible inverter-driven AWHPs and highlighted that the HPs seasonal efficiency is greatly affected by the climate of the location and the HP sizing. They also concluded that the HP seasonal efficiency increases by applying a weather compensation control system. Naldi et al. [16] estimated the SCOP of fixed-capacity mono-compressors, multi-compressors, and inverter-driven HPs installed in several buildings with different thermal insulation and concluded that HPs with inverter-driven compressors appear to have optimal seasonal efficiency. Dongellini et al. [17] presented an operation simulation of three AWHPs (on-off mono-compressor, multi-compressor, and inverter-driven) in 11 different buildings in Bologna and highlighted the importance of the HP sizing. More specifically, inverter-driven HPs show the highest seasonal performance when the nominal heating capacity is equal to the design load, while on-off compressor HPs have maximum SCOP when they are slightly oversized. In another work, Dongellini et al. [18] calculated the SEER and SCOP of three AWHPs (on-off mono-compressor, multi-compressor and inverterdriven) installed in an office building placed in three representative cities and pointed-out that the correct sizing of a HP is an important factor that affects the overall efficiency, while the inverter-driven and the multi-compressor HPs show higher seasonal efficiency than the ones with on-off mono-compressor. Dongellini and Morini [19] investigated the effect of on-off cycling, during partial load operation, on the SCOP of fixed-capacity (single-stage units and multi-stage units) and inverter-driven AWHPs. They presented that the energy losses that appear during the on-off cycle operation have a significant impact on the energy performance only for single-stage units (decrease of the SCOP up to $12 \%)$. Dongellini et al. [20] examined the influence of the heat pump size on the seasonal performance of a hybrid HP system, namely an inverter-driven HP coupled with a back-up heater either with electric resistances or condensing gas boiler. They demonstrated that the overall seasonal efficiency of this system can be increased by up to $22 \%$ compared to the efficiency of the gas boiler, if the heat pump covers the $74 \%$ of the building design thermal load. Huchtemann and Müller [13] presented a simulation study of an AWHP operation with a control strategy by adapting the water supply temperature according to the building actual thermal load. They showed that, with this control strategy, the overall seasonal performance increases by 0.19 (from 2.65 to 2.84), while the primary energy consumption decreases by $6.8 \%$. In Greece, Mouzeviris and Papakostas [4] calculated the SCOP of 66 AWHPs (fixed-capacity and inverter-driven) installed in four representative cities of the four Greek climate zones. The numerical results of this work showed the influence of factors such as the climate, the water outlet temperature, the use of weather compensation, and the HP's compressor technology on the AWHPs seasonal efficiency. In another work, Mouzeviris and Papakostas [21] examined the impact of the HPs sizing on the SCOP of a fixed-capacity and an inverter-driven HP in correlation with the climate of the four Greek climate zones, the water outlet temperature, and the control system. Their results highlighted that the inverter-driven HPs show optimal performance when they are sized at the design outdoor air temperature, while in the case of the fixed-capacity HPs, they show optimal performance when they are down-sized, which is consistent with the results of Dongellini [17]. Recent studies have shown that the HP seasonal performance increases when a thermal energy storage tank (TEST) is integrated in the HP operation. Wu et al. [22] presented a novel operation strategy in a heating system consisting of an AWHP integrated with a TEST. The heating system was monitored for approximately 3.5 months (1 December to 11 March), and the results showed an improvement of the SCOP (2.95) by $26.1 \%$ compared to the SCOP (2.34) of the continuous HP operation without a TEST. Kudela et al. [23] presented a computational model of a system, consisting of a $\mathrm{HP}$, a low-temperature heat storage and control unit. In the building examined in this study, a low-temperature heating system with a maximum water temperature of $45^{\circ} \mathrm{C}$ was installed. There were two low-temperature heat sources available that were used alternatively by the HP, depending on the outdoor air temperature. Their results showed that, by applying a control strategy with a HP control algorithm using the meteorological data prediction, the use of the low-temperature thermal energy storage tank increases the 
SCOP by approximately $5.2 \%$. In another work, Pospisil et al. [24] developed a model of a heating system combined with a TEST in which they highlighted the relations of the SCOP with the TEST capacity and the heat pump's control system. They used an algorithm of predictive control for different operating parameters and TEST capacities and concluded that the application of a predictive control increases the SCOP by $23 \%$ and decreases the annual energy consumption by $20 \%$. Renaldi et al. [25] presented an optimization framework with the integration of a TEST in an AWHP heating system for different electricity tariffs. They showed that combining an AWHP with a TEST reduces the operational cost compared to the HP-only scenario cost.

The aim of this paper is to present a comparative analysis of the seasonal coefficient of performance in heating mode (seasonal coefficient of performance-SCOP) of AWHPs, which are available in the Greek market. The sample includes a total of 100 models from 12 manufacturers. The comparative analysis is based on (a) the technical specifications of the various models given in the technical data books of each company, (b) the climate of the location where the HP is installed, (c) the water outlet temperature to the heating system $\left(\mathrm{T}_{\mathrm{w}, \text { outlet }}\right)$, and (d) the HP's control system. The calculation of the seasonal efficiency was performed with a special software that was developed, based on the method proposed by the standard EN14825 [26]. This work is an extension and update of the work [4] but also a more detailed investigation of the correlation of the SCOP with all the above parameters and with the HPs' heating capacity. Furthermore, in the present study, it was investigated under which conditions the SCOP is equal or greater than 3 , which is a criterion for the economic operation of a HP but also for its characterization as RES. The selected companies are, alphabetically, Carrier [27], Climaveneta [28], Daikin [29], DeDietrich [30], Hitachi [31], LG [32], Mitsubishi [33], Rhoss [34], Stiebel Eltron [35], Toshiba [36], Trane [37], and York [38].

\section{Methodology-Climate Data}

The seasonal coefficient of performance (SCOP) is defined as the ratio of the total energy provided by the HP to the heating system (in thermal $\mathrm{kWh}$ ) to the total annual energy (in kWh of electricity) consumed for heating operation and is an index of the HP's operating costs $[4,21,26]$. The SCOP calculation methodology is described in detail in a previous work by the authors [39]. The methodology requires appropriate climatic data, which are called bin data and are the occurrence frequency of the outdoor air temperature (of the region in which the HP is installed) at various temperature intervals with a range of 1 or $2 \mathrm{~K}$. The EN14825 standard classifies Europe into three climate zones, warmer, medium, and colder, with outdoor design temperatures for the calculation of heat losses $\left(\mathrm{T}_{\mathrm{des}}\right)$ of 2 , -10 , and $-22{ }^{\circ} \mathrm{C}$, respectively, and provides the occurrence frequency of the outdoor air temperatures for these three zones. Greece is classified in the warmer zone, and, according to EN14825, the climate data of the warmer zone should be used for the calculation of SCOP. However, it has been shown that comparing the SCOP values obtained by using the climate data of the standard EN14825 with those obtained by real climate data from different regions, large discrepancies occur in many cases [4,39]. More specifically, in Greek regions with milder climates (Heraklion and Athens), the calculated average seasonal efficiency in heating with actual temperature data is $5 \%$ higher when compared to that resulting from the standard, while in areas with colder climates (Thessaloniki and Florina), there are deviations from $8 \%$ to $28 \%$. The analysis in the present work was performed with the use of climatic data of four cities [40-43], representative of the four climatic zones of Greece [44]. These cities are Ierapetra (zone A), Athens (zone B), Thessaloniki (zone C), and Florina (zone D). The $\mathrm{T}_{\text {des }}$ in these four cities are $7,2,-2$, and $-7.5^{\circ} \mathrm{C}$, respectively [45].

When the outdoor air temperature is equal to $\mathrm{T}_{\mathrm{des}}$, the heat load of the building is equal to the design heat losses, namely the $100 \%$. On the other hand, when the outdoor air temperature is equal to a temperature called balance temperature $\left(T_{b a l}\right)$, which according to [26] is $16^{\circ} \mathrm{C}$, the heat load of the building is equal to zero. Based on the assumption that the heat load is linearly correlated to the outdoor air temperature, the duration of operation 
of the heating system (in hours) can be calculated. For temperatures above $T_{\text {des }}$, the heat load of the building is equal to a percentage of the design load and in temperatures below the $T_{\text {des }}$ it exceeds it. In Table 1, data for the duration of the heating season and of the building heat load, for the four representative cities of this study, are given. Specifically, the temperature intervals (bins), their middle values, the frequency of occurrence (h) of the outdoor air temperature in each bin, and the heat load values in percentage (\%) of the design heat load are sequentially shown in columns with numbers $1,2,3$, and 4 , while in columns with number 5 , the hours during which the heat load of a space/building/thermal zone is equal or exceeds the corresponding percentage of the design heat load in Column 4 is given.

Table 1. Hours during which the space/building heat load equals or exceeds each given percentage of design heat load for the 4 representative cities.

\begin{tabular}{|c|c|c|c|c|c|c|c|c|c|c|c|c|c|}
\hline \multirow[b]{2}{*}{ (1) } & \multirow[b]{2}{*}{ (2) } & \multicolumn{3}{|c|}{$\begin{array}{c}\text { Ierapetra } \\
\left(\mathrm{T}_{\text {des }}=7^{\circ} \mathrm{C}\right)\end{array}$} & \multicolumn{3}{|c|}{$\begin{array}{c}\text { Athens } \\
\left(\mathrm{T}_{\text {des }}=2{ }^{\circ} \mathrm{C}\right)\end{array}$} & \multicolumn{3}{|c|}{$\begin{array}{l}\text { Thessaloniki } \\
\left(\mathrm{T}_{\text {des }}=-2^{\circ} \mathrm{C}\right)\end{array}$} & \multicolumn{3}{|c|}{$\begin{array}{c}\text { Florina } \\
\left(\mathrm{T}_{\text {des }}=-7.5^{\circ} \mathrm{C}\right)\end{array}$} \\
\hline & & (3) & (4) & (5) & (3) & (4) & (5) & (3) & (4) & (5) & (3) & (4) & (5) \\
\hline 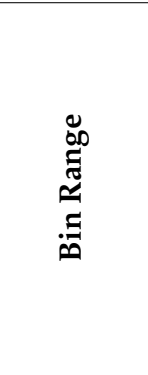 & 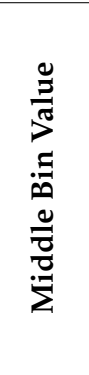 & 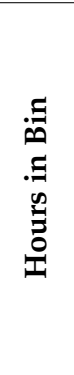 & 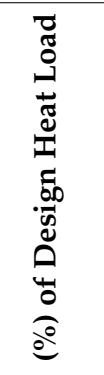 & 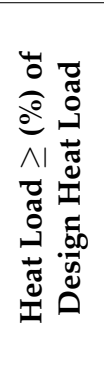 & 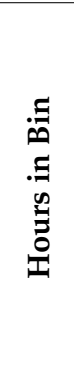 & 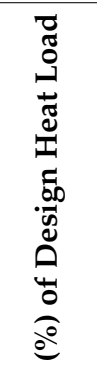 & 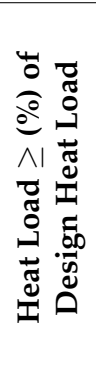 & 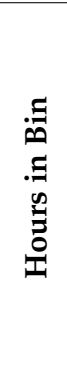 & 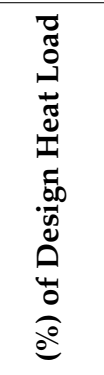 & 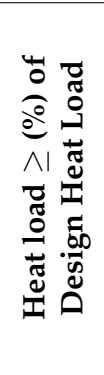 & 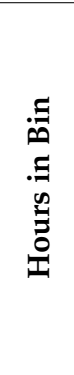 & 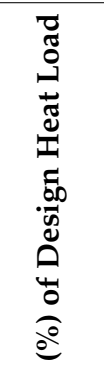 & 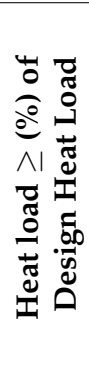 \\
\hline$\left({ }^{\circ} \mathrm{C}\right)$ & $\left({ }^{\circ} \mathrm{C}\right)$ & (h) & & (h) & & & (h) & (h) & & (h) & (h) & & (h) \\
\hline$-18 /-16$ & -17 & - & - & - & - & - & - & - & - & - & 1 & 140.4 & 1 \\
\hline$-16 /-14$ & -15 & - & - & - & - & - & - & - & - & - & 2 & 131.9 & 3 \\
\hline$-14 /-12$ & -13 & - & - & - & - & - & - & - & - & - & 6 & 123.4 & 9 \\
\hline$-12 /-10$ & -11 & - & - & - & - & - & - & - & - & - & 15 & 114.9 & 24 \\
\hline$-10 /-8$ & -9 & - & - & - & - & - & - & - & - & - & 28 & 106.4 & 52 \\
\hline$-8 /-6$ & -7 & - & - & - & - & - & - & - & - & - & 69 & 97.9 & 121 \\
\hline$-6 /-4$ & -5 & - & - & - & 2 & 150.0 & 2 & 10 & 116.7 & 10 & 128 & 89.4 & 249 \\
\hline$-4 /-2$ & -3 & - & - & - & 4 & 135.7 & 6 & 22 & 105.6 & 32 & 226 & 80.9 & 475 \\
\hline$-2 / 0$ & -1 & - & - & - & 6 & 121.4 & 12 & 54 & 94.4 & 86 & 357 & 72.3 & 832 \\
\hline $0 / 2$ & 1 & 22 & 166.7 & 22 & 36 & 107.1 & 48 & 171 & 83.3 & 257 & 481 & 63.8 & 1313 \\
\hline $2 / 4$ & 3 & 34 & 144.4 & 56 & 100 & 92.9 & 148 & 300 & 72.2 & 557 & 569 & 55.3 & 1882 \\
\hline $4 / 6$ & 5 & 93 & 122.2 & 149 & 215 & 78.6 & 363 & 407 & 61.1 & 964 & 591 & 46.8 & 2473 \\
\hline $6 / 8$ & 7 & 197 & 100.0 & 346 & 379 & 64.3 & 742 & 582 & 50.0 & 1546 & 584 & 38.3 & 3057 \\
\hline $8 / 10$ & 9 & 374 & 77.8 & 720 & 552 & 50.0 & 1294 & 697 & 38.9 & 2243 & 555 & 29.8 & 3612 \\
\hline $10 / 12$ & 11 & 571 & 55.6 & 1291 & 725 & 35.7 & 2019 & 670 & 27.8 & 2913 & 496 & 21.3 & 4108 \\
\hline $12 / 14$ & 13 & 724 & 33.3 & 2015 & 824 & 21.4 & 2843 & 628 & 16.7 & 3541 & 407 & 12.8 & 4515 \\
\hline $14 / 16$ & 15 & 781 & 11.1 & 2796 & 766 & 7.1 & 3609 & 536 & 5.6 & 4077 & 282 & 4.3 & 4797 \\
\hline
\end{tabular}

Figure 1 shows the percentages of the design heat load (\%) for each of the four cities and the corresponding hours observed, as shown in the last two columns of Table 1 (Columns 4 and 5) for each city. The area enclosed by the curve and the two axes of the diagram is proportional to the total energy required for heating in a winter season. During the hours when the percentage of the load is less than or equal to $100 \%$, the heating demand is covered by the operation of the HP, while for percentages greater than $100 \%$, it is covered by the auxiliary heating source (e.g., electrical resistances). In the case of the city of Ierapetra, the area corresponding to a percentage of design load greater than $100 \%$ is $5.3 \%$ of the total area. It is characteristic that, in the other cities (Athens, Thessaloniki, and Florina), the respective percentages are significantly lower $(0.7 \%, 0.3 \%$, and $0.4 \%$, respectively). Additionally, in Ierapetra, the total hours under the heating design temperature are equal to $346 \mathrm{~h}$ (Figure 1, 
point $\mathrm{A})$, which is particularly greater compared to the corresponding of the three other cities $(98,59$, and $104 \mathrm{~h}$ for Athens, Thessaloniki, and Florina, points C, D, and B on the horizontal axis, respectively).

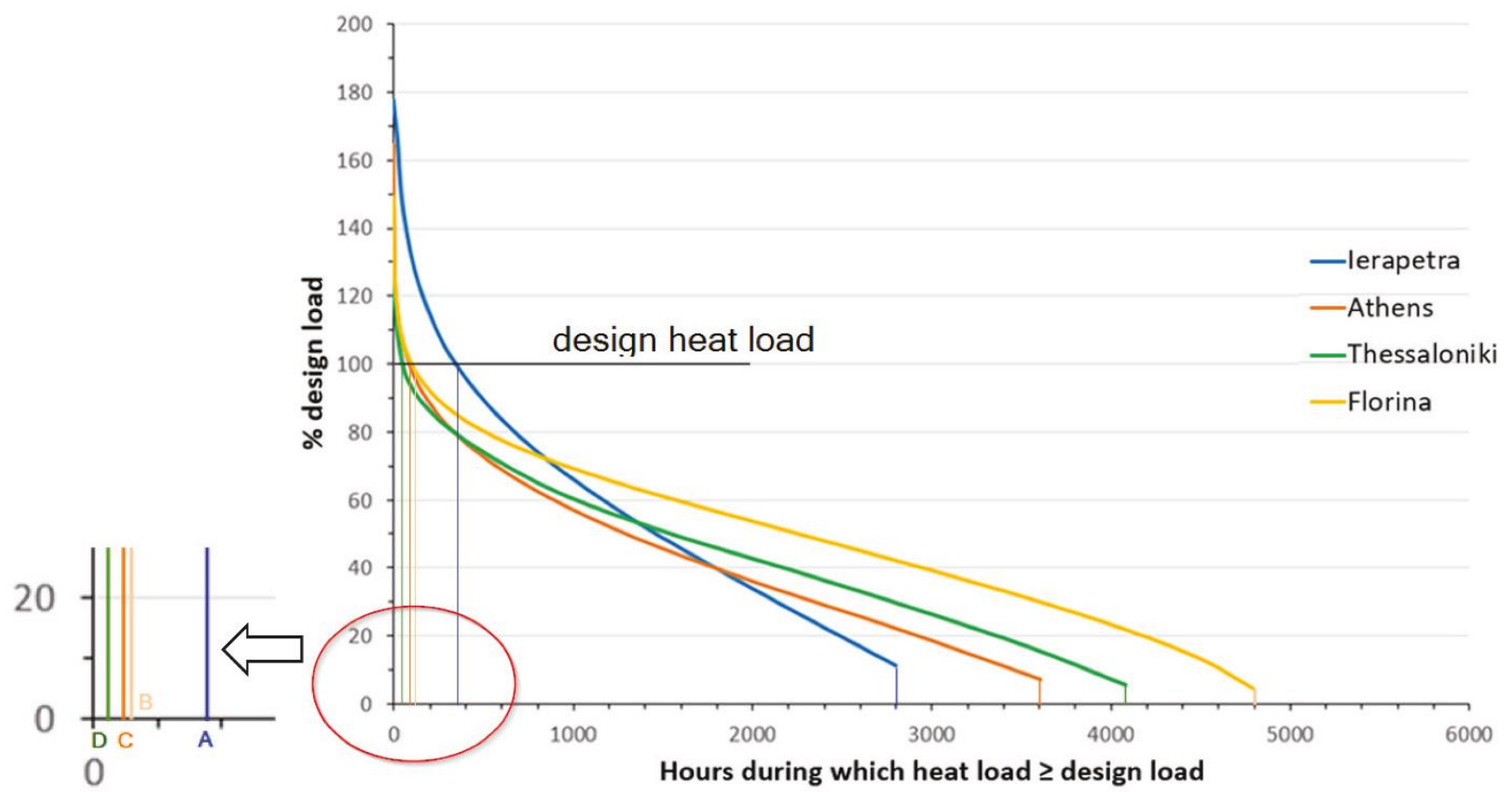

Figure 1. Heating period duration (h) for each city and number of hours during which the heat load $\geq$ design heat load.

Of course, the bin data are the result of statistical processing of long periods of temperature records and do not mean that these temperatures are observed every year, but they are likely to be observed in years with severe winters. These two remarks are important, as will be seen from the results of this work.

Figure 2 shows an example of a typical heating capacity characteristics curve of an air-to-water HP (blue line) with the corresponding building's heat load curve (red line), for a $\mathrm{T}_{\text {des }}=-2{ }^{\circ} \mathrm{C}$ and with $\mathrm{T}_{\text {bal }}=16{ }^{\circ} \mathrm{C}$. At the $\mathrm{T}_{\text {des }}$, the corresponding design heat load $\left(\mathrm{P}_{\text {des }}\right)$ is $30 \mathrm{~kW}$, while at the same temperature, the HP's heating capacity $\left(\mathrm{P}_{\mathrm{hp}}\right)$ is $18 \mathrm{KW}$ (point $\mathrm{C})$. The remaining heat load $(12 \mathrm{~kW})$, below the temperature corresponding to point $\mathrm{B}$, is covered by the operation of the electrical resistances. The temperature at which the HP covers $100 \%$ of the heat load (point $\mathrm{B}$ ) is called bivalent temperature $\left(\mathrm{T}_{\text {biv }}\right.$ ) and in this case is approximately equal to $3^{\circ} \mathrm{C}$. When the outdoor air temperature is higher than $\mathrm{T}_{\mathrm{biv}}$, the HP's heating capacity is greater than the building's heat load and the HP operates at partial load either by adjusting its heating capacity (HP with inverter-driven compressor) or by operating with on-off cycles (HP with fixed-capacity compressor). The heat supply from the HP can also be adjusted with weather compensation, namely by adjusting the water supply temperature to the heating system. In addition, the HP's heating capacity curve stops at a minimum temperature (TOL-operation limit temperature), below which the HP stops its operation. In the present work, for the calculation of SCOP, it was assumed that the design load of the building/space/thermal zone in each case study is equal to the maximum heating capacity of the heat pump. In other words, in each case, the heating capacity of the HP is selected equal to the design load of the building, and the auxiliary heat source (electrical heaters) operates only if the outdoor air temperature is lower than $\mathrm{T}_{\text {des }}$. Therefore, according to the data presented in Figure 1 and Table 1, an air-to-water heating system is likely to operate with electrical heaters for $5.3 \%, 0.7 \%, 0.3 \%$, and $0.4 \%$ of the hours of the heating season in Ierapetra, Athens, Thessaloniki, and Florina, respectively. 


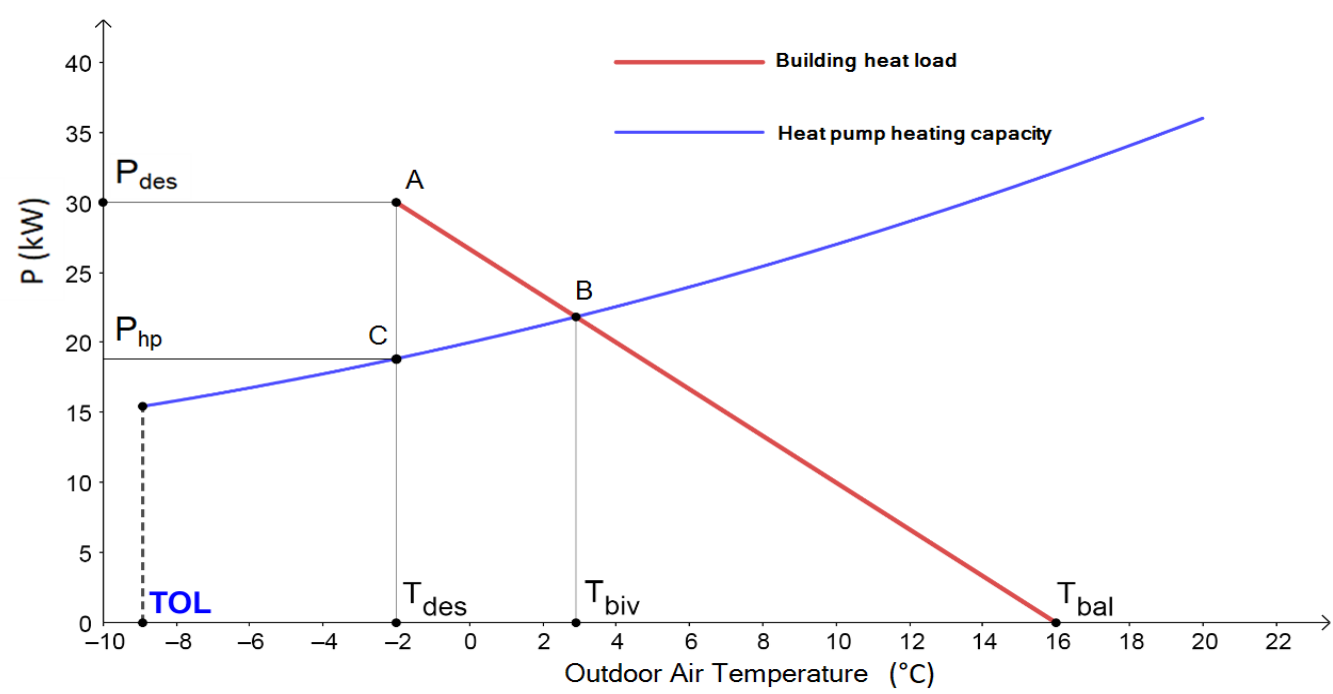

Figure 2. Building heat load line and HP's heating capacity curve.

\section{Description of the Sample}

The results presented in this work are based on the data collected from the technical data books of 100 AWHP models from 12 manufacturers. The nominal heating capacity of the sample ranges from 2 to $50 \mathrm{~kW}$, while 58 models have a fixed capacity compressor and 42 models an inverter-driven compressor. The operation characteristics that were taken from the technical data books are the HP's heating capacity (W), the electrical power input $(\mathrm{W})$, and the corresponding coefficient of performance in heating (COP), as a function of the outdoor air temperature and the water outlet temperature from the HP. Table 2 presents in detail the 12 manufacturers along with the corresponding AWHP models.

Table 2. Heat pumps manufacturers, types, and number of models (in brackets).

\begin{tabular}{|c|c|}
\hline Company & Model Type (Models in Sample) \\
\hline \multirow{5}{*}{ CARRIER } & 30AWH (7) \\
\hline & 30RQ (3) \\
\hline & 30RQA (3) \\
\hline & 30RQV (1) \\
\hline & 38AW (5) \\
\hline CLIMAVENETA & AWRMTD2 (4) \\
\hline \multirow{4}{*}{ DAIKIN } & ERHQ (3) \\
\hline & EUWP (4) \\
\hline & EUWYN (4) \\
\hline & EWYQ (5) \\
\hline DE DIETRICH & AWHP (5) \\
\hline HITACHI & RHUE(5) \\
\hline LG & AHUW (10) \\
\hline MITSUBISHI & PUHZ (7) \\
\hline
\end{tabular}


Table 2. Cont.

\begin{tabular}{cc}
\hline Company & Model Type (Models in Sample) \\
\cline { 2 - 2 } RHOSS & THAETY (3) \\
\cline { 2 - 2 } & THAITY (2) \\
\cline { 2 - 2 } STIEBEL ELTRON & THCETY (2) \\
\hline TOSHIBA & WPL (6) \\
\hline TRANE & CXA (7) \\
\hline YORK & FLEX (1) \\
\hline
\end{tabular}

\section{Discussion}

Figures 3-6 show the SCOP values in relation to the heating capacity of the AWHPs of the sample for the cities of Ierapetra, Athens, Thessaloniki, and Florina, respectively. The results are presented considering water supply temperatures of 35,45 , and $55^{\circ} \mathrm{C}$ and a control system with or without weather compensation.

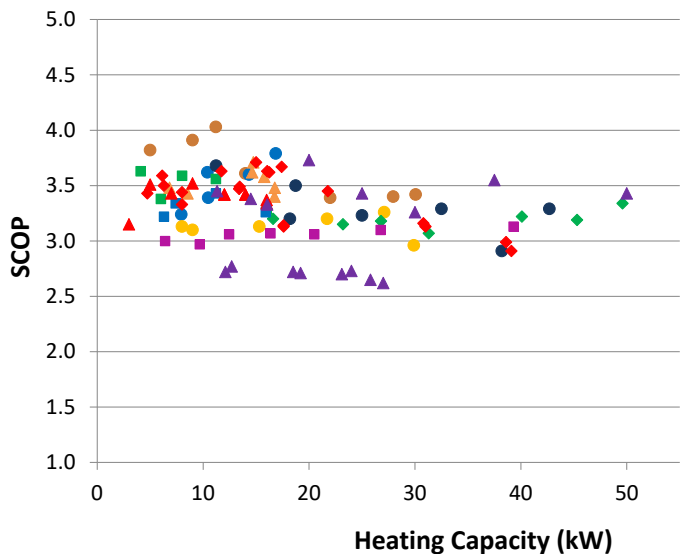

(a)

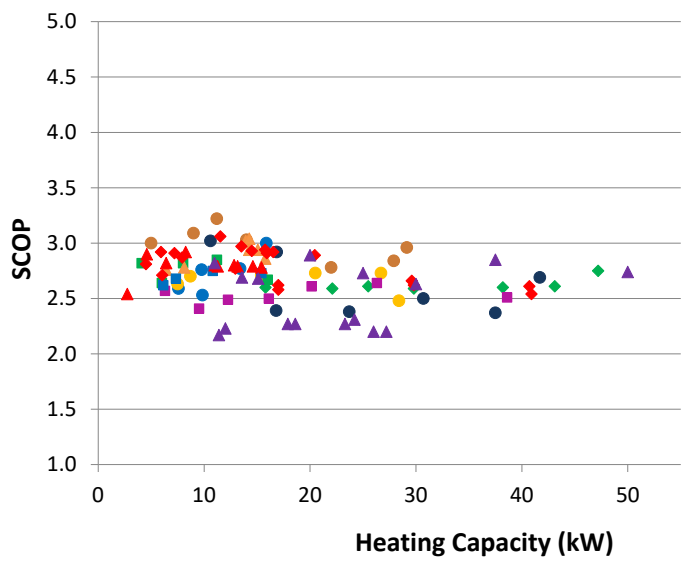

(c)

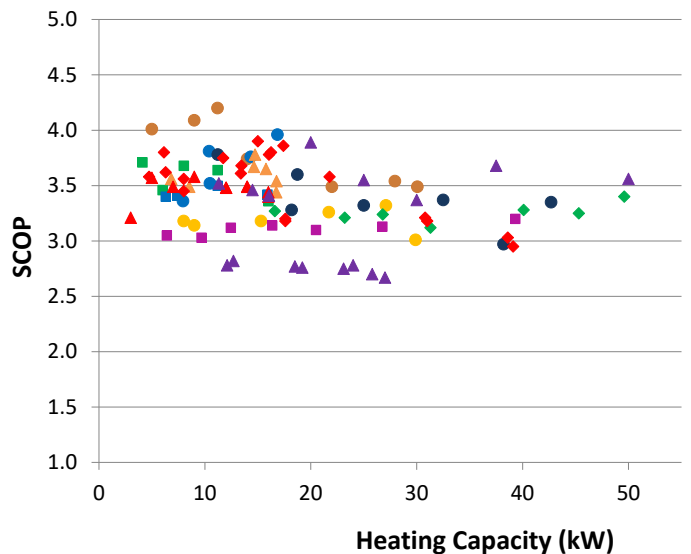

(b)

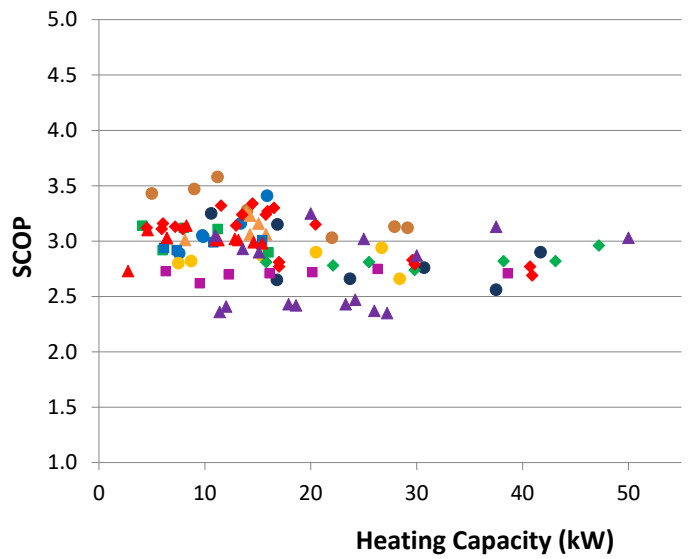

(d)

Figure 3. Cont.

- Company 1
- Company 2
- Company 3
- Company 4
- Company 5
- Company 6
- Company 7
Company 8
- Company 9
Company 10
C Company 11
- Company 12

Company 2

Company 4

Company 5

- Company 7

Company 9

- Company 10

Company 11

(2)
- Company 1

- Company 2

- Company 3

- Company 4

- Company 5

- Company 6

- Company 7

$\triangle$ Company 8

- Company 9

- Company 10

A Company 11

A Company 12

Company 1

- Company 2

- Company 3

- Company 4

- Company 5

- Company 6

- Company 7

$\triangle$ Company 8

- Company 9

- Company 10

A Company 11

A Company 12 


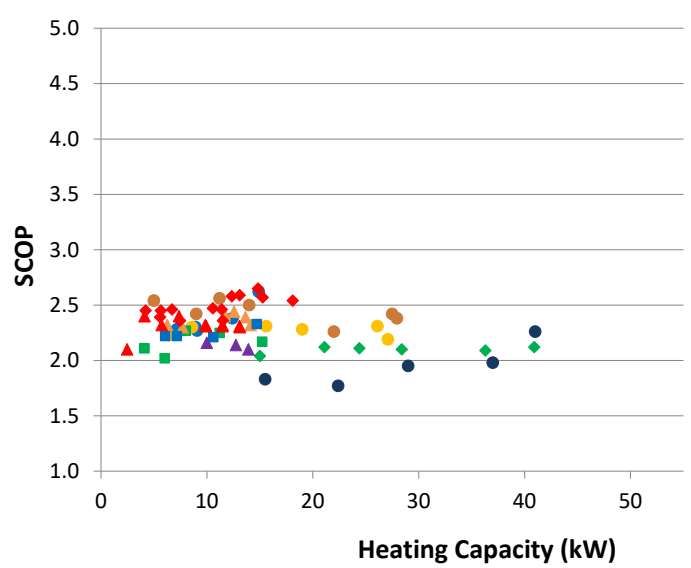

(e)

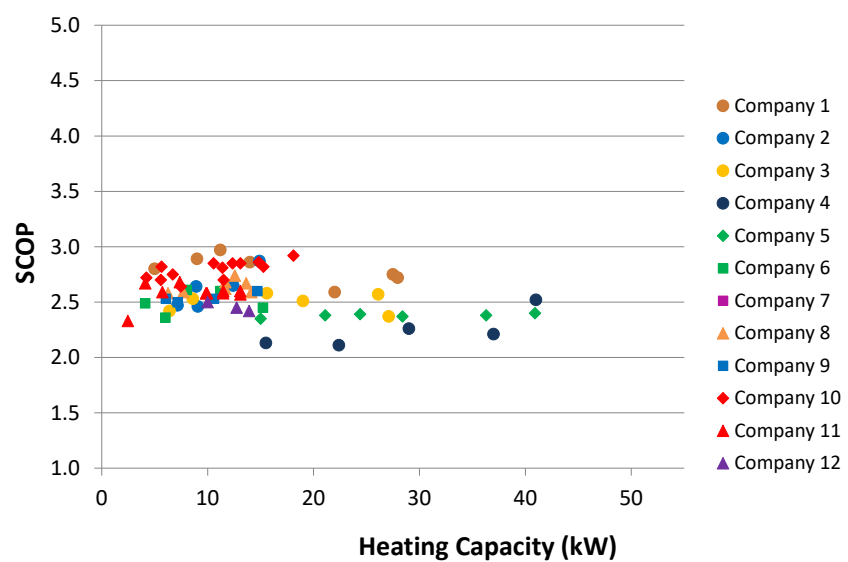

(f)

Figure 3. SCOP against HP's heating capacity for the city of Ierapetra: (a) $\mathrm{T}_{\mathrm{w} \text {,outlet }}=35^{\circ} \mathrm{C}$-without compensation, (b) $\mathrm{T}_{\mathrm{w} \text {,outlet }}=35^{\circ} \mathrm{C}$-with compensation, (c) $\mathrm{T}_{\mathrm{w} \text {,outlet }}=45^{\circ} \mathrm{C}$-without compensation, (d) $\mathrm{T}_{\mathrm{w} \text {, outlet }}=45{ }^{\circ} \mathrm{C}$-with compensation, (e) $\mathrm{T}_{\mathrm{w} \text {,outlet }}=55{ }^{\circ} \mathrm{C}$-without compensation, (f) $\mathrm{T}_{\mathrm{w} \text {, outlet }}=55^{\circ} \mathrm{C}$-with compensation.

In the case of Climatic Zone A (Ierapetra), the values of SCOP range from 1.77 to 4.2 , as shown in Figure 3, depending on the $\mathrm{T}_{\mathrm{w} \text {,outlet }}$ to the heating system, the control system, and the compressor technology. More specifically, in the case of HPs with heating capacity up to $20 \mathrm{~kW}$, the SCOP ranges from 2.71 to 4.2 , from 2.17 to 3.58 , and from 1.83 to 2.87 for $\mathrm{T}_{\mathrm{w} \text {,outlet }} 35,45$, and $55^{\circ} \mathrm{C}$, respectively. For HPs with heating capacities from 20 to $50 \mathrm{~kW}$, the ranges of SCOP values are from 2.62 to 3.68, from 2.2 to 3.15, and from 1.77 to 2.92 for $\mathrm{T}_{\mathrm{w} \text {,outlet }} 35,45$, and $55^{\circ} \mathrm{C}$, respectively.

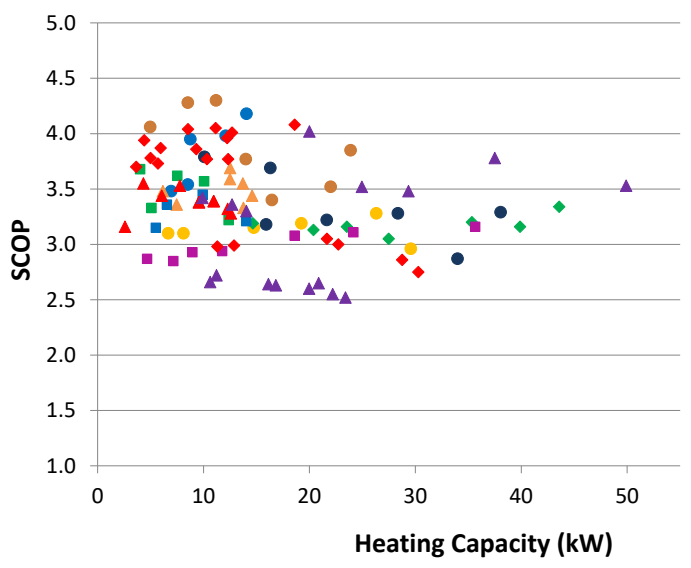

(a)

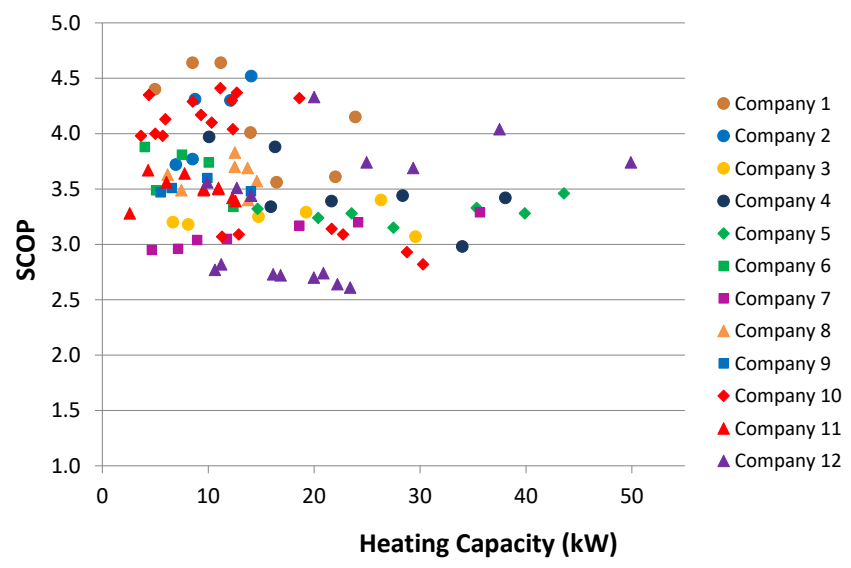

(b)

Figure 4. Cont. 


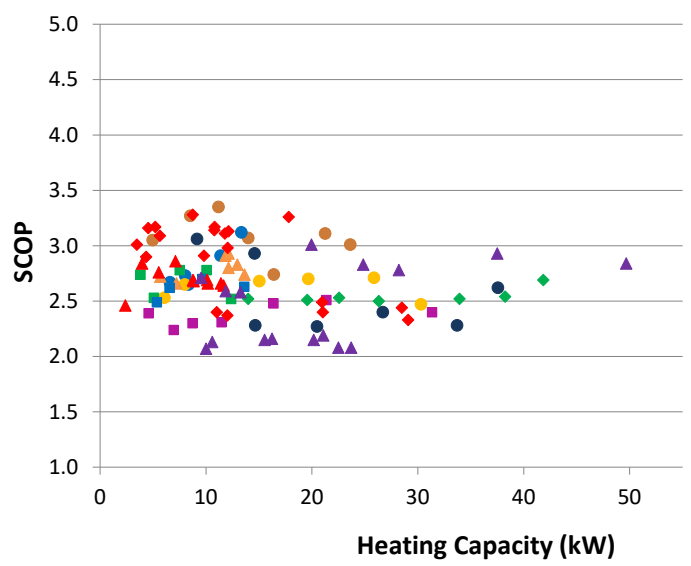

(c)

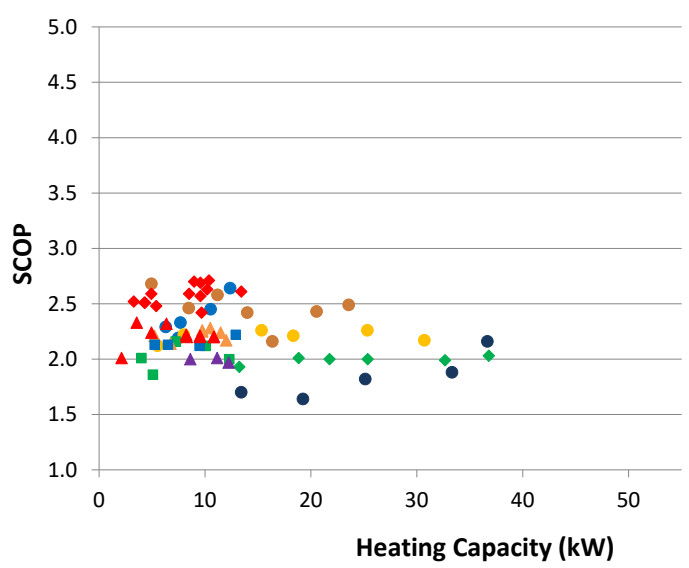

(e)
- Company 1

- Company 2

- Company 3

- Company 4

- Company 5

- Company 6

- Company 7

$\triangle$ Company 8

- Company 9

- Company 10

A Company 11

A Company 12

- Company 1

- Company 2

- Company 3

- Company 4

- Company 5

- Company 6

- Company 7

Company 8

- Company 9

- Company 10

Company 11

A Company 12

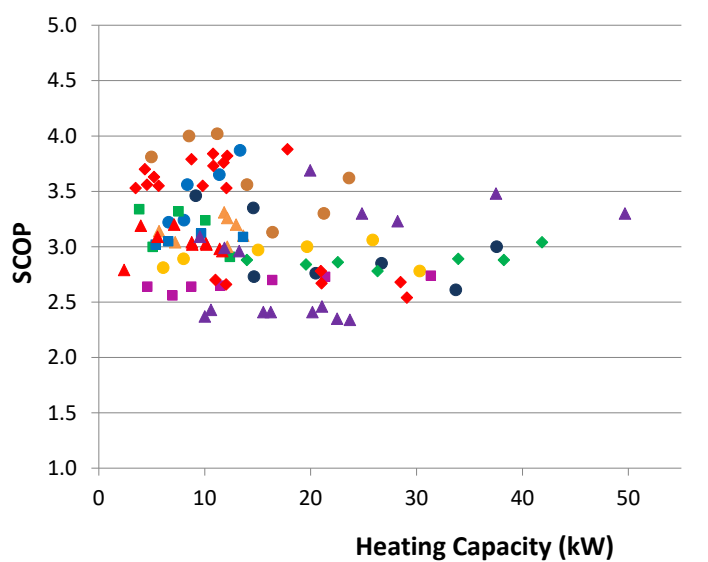

- Company 1

- Company 2

Company 3

- Company 4

- Company 5

- Company 6

- Company 7

$\triangle$ Company 8

- Company 9

- Company 10

A Company 11

A Company 12

(d)

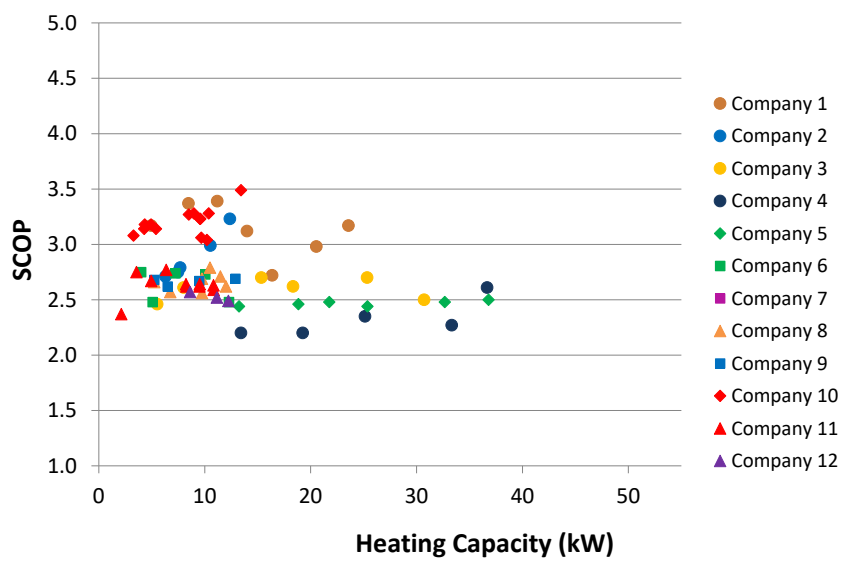

(f)

Figure 4. SCOP against HP's heating capacity for the city of Athens: (a) $\mathrm{T}_{\mathrm{w} \text {,outlet }}=35^{\circ} \mathrm{C}$-without compensation, (b) $\mathrm{T}_{\mathrm{w} \text {,outlet }}=35{ }^{\circ} \mathrm{C}$-with compensation, (c) $\mathrm{T}_{\mathrm{w} \text {,outlet }}=45^{\circ} \mathrm{C}$-without compensation, (d) $\mathrm{T}_{\mathrm{w} \text {, outlet }}=45{ }^{\circ} \mathrm{C}$-with compensation, (e) $\mathrm{T}_{\mathrm{w} \text {,outlet }}=55{ }^{\circ} \mathrm{C}$-without compensation, (f) $\mathrm{T}_{\mathrm{w} \text {,outlet }}=55^{\circ} \mathrm{C}$-with compensation.

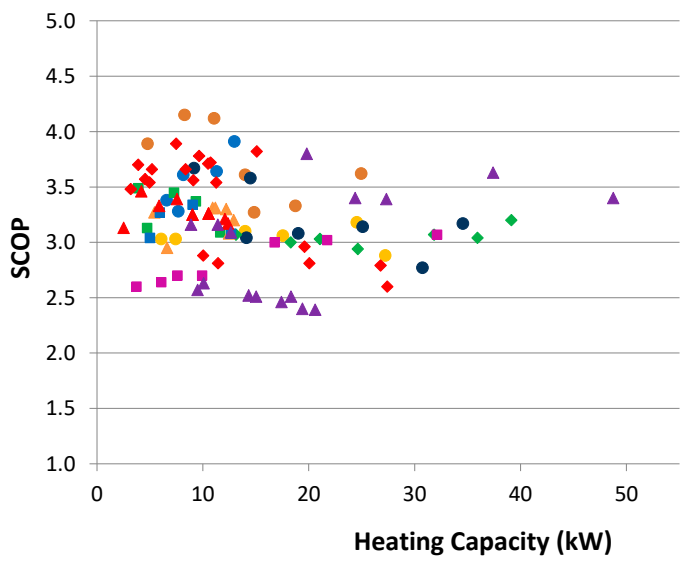

(a)
- Company 1 - Company 2 - Company 3 - Company 4 - Company 5 - Company 6 - Company 7 $\triangle$ Company 8 - Company 9 - Company 10 A Company 11 A Company 12

Figure 5. Cont.

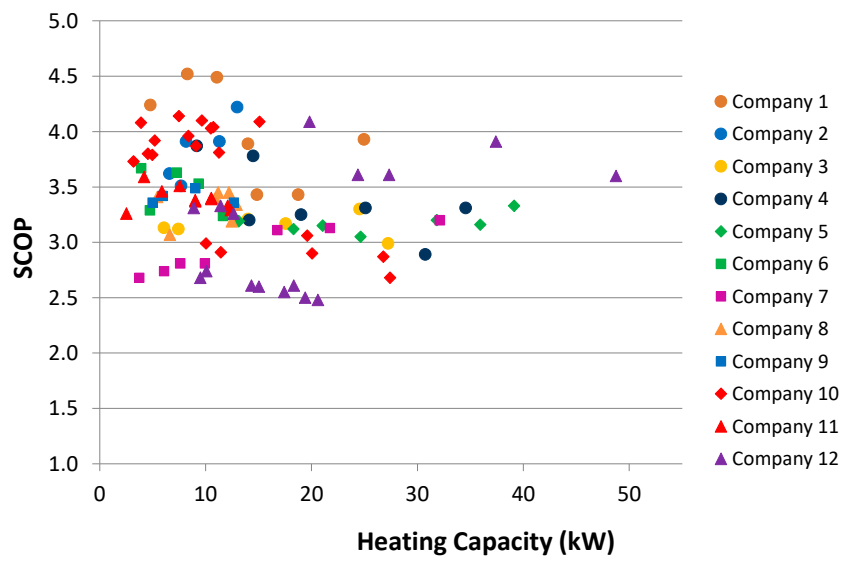

(b) 


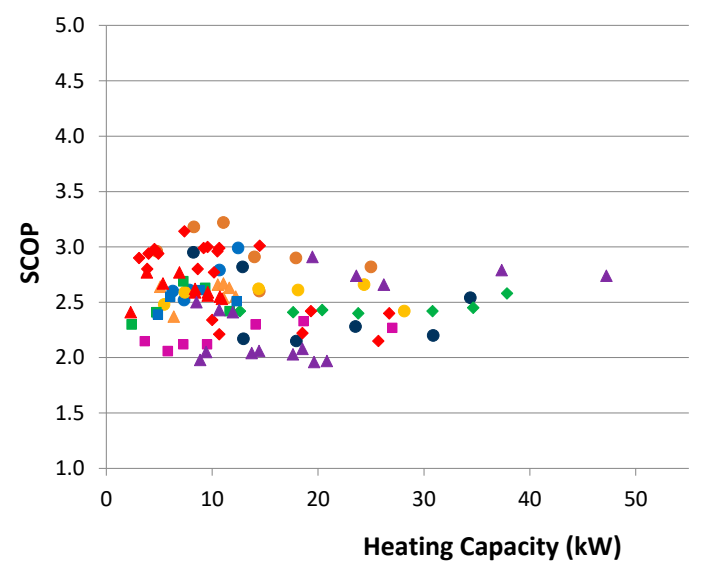

(c)

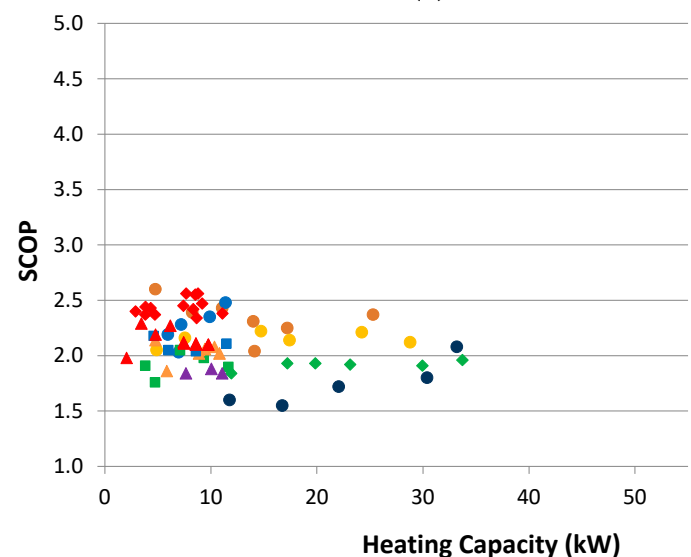

(e)
- Company 1

- Company 2

- Company 3

- Company 4

- Company 5

- Company 6

- Company 7

$\triangle$ Company 8

- Company 9

- Company 10

A Company 11

A Company 12

- Company 1

- Company 2

- Company 3

- Company 4

- Company 5

- Company 6

- Company 7

$\triangle$ Company 8

- Company 9

- Company 10

A Company 11

A Company 12

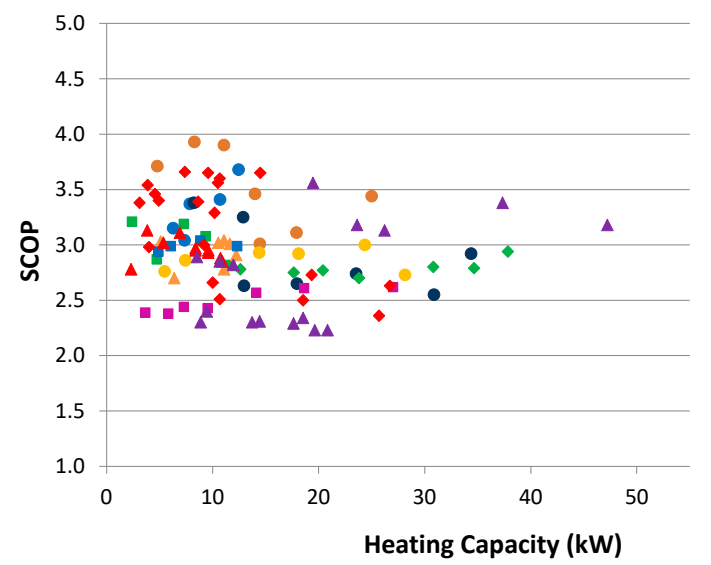

(d)

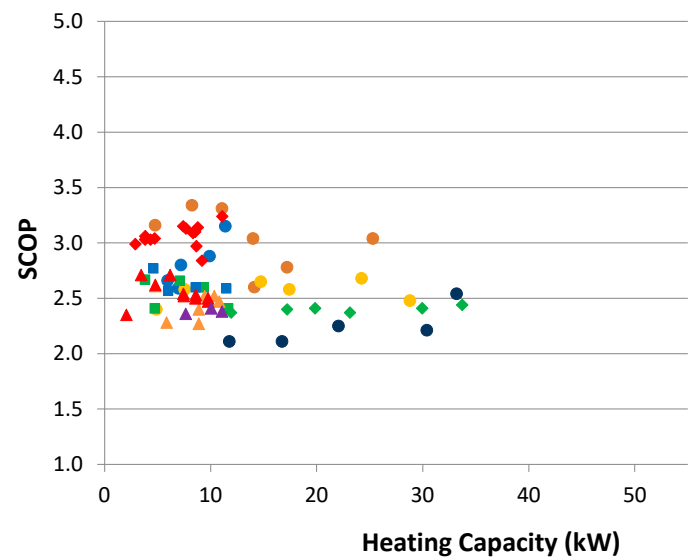

(f)
- Company 1

- Company 2

- Company 3

- Company 4

- Company 5

- Company 6

- Company 7

$\triangle$ Company 8

- Company 9

- Company 10

A Company 11

A Company 12

Figure 5. SCOP against HP's heating capacity for the city of Thessaloniki: (a) $\mathrm{T}_{\mathrm{w} \text {,outlet }}=35{ }^{\circ} \mathrm{C}-$ without compensation, (b) $\mathrm{T}_{\mathrm{w} \text {,outlet }}=35{ }^{\circ} \mathrm{C}$-with compensation, (c) $\mathrm{T}_{\mathrm{w} \text {, outlet }}=45^{\circ} \mathrm{C}$-without compensation, (d) $\mathrm{T}_{\mathrm{w} \text {, outlet }}=45^{\circ} \mathrm{C}$-with compensation, (e) $\mathrm{T}_{\mathrm{w} \text {,outlet }}=55^{\circ} \mathrm{C}$-without compensation, (f) $\mathrm{T}_{\mathrm{w} \text {,outlet }}=55^{\circ} \mathrm{C}$-with compensation.

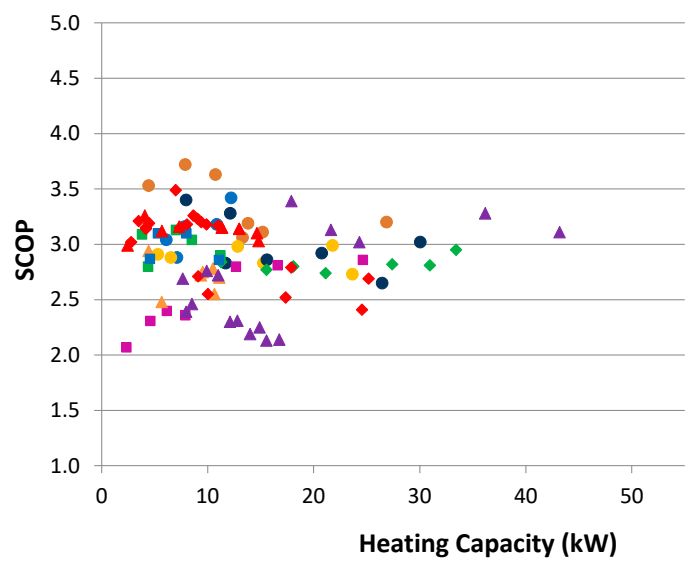

(a)

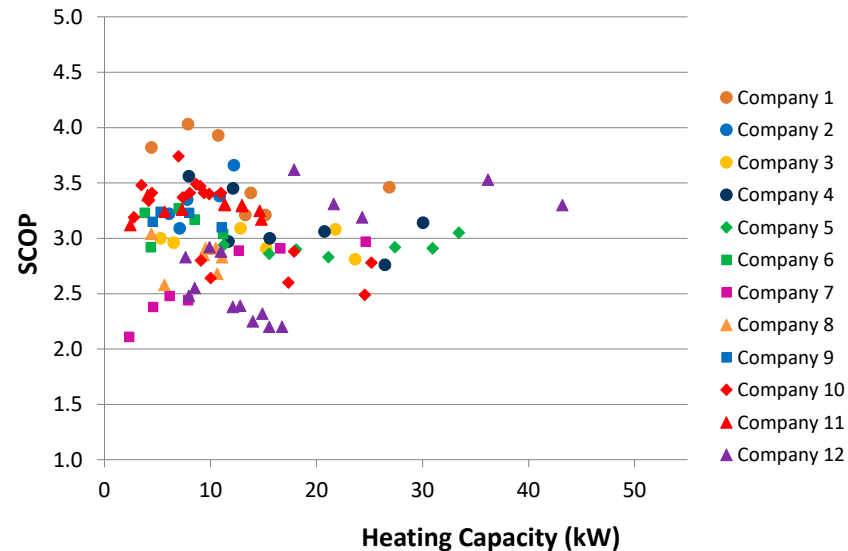

(b)

Figure 6. Cont. 


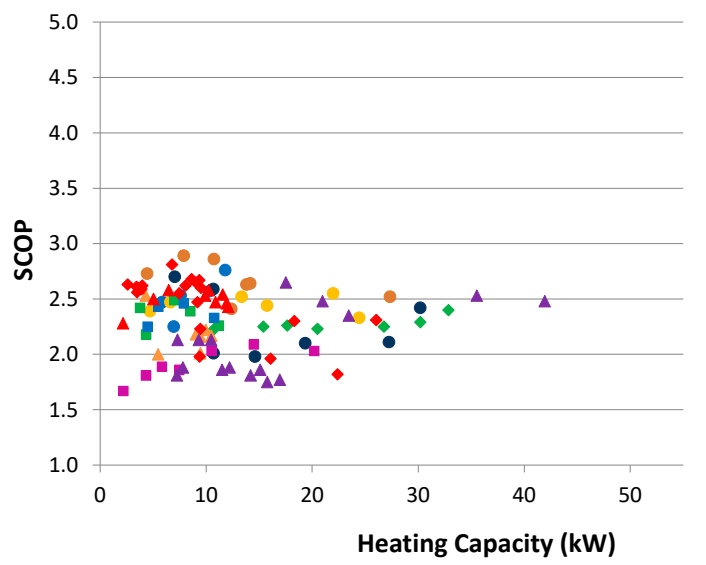

(c)

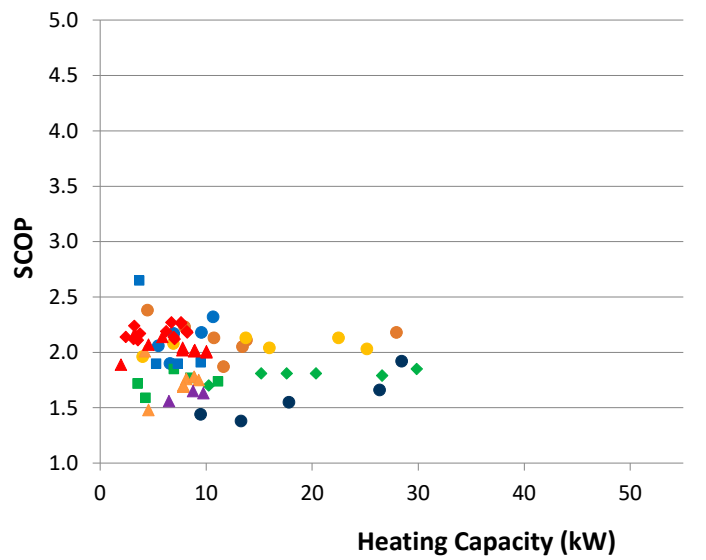

(e)

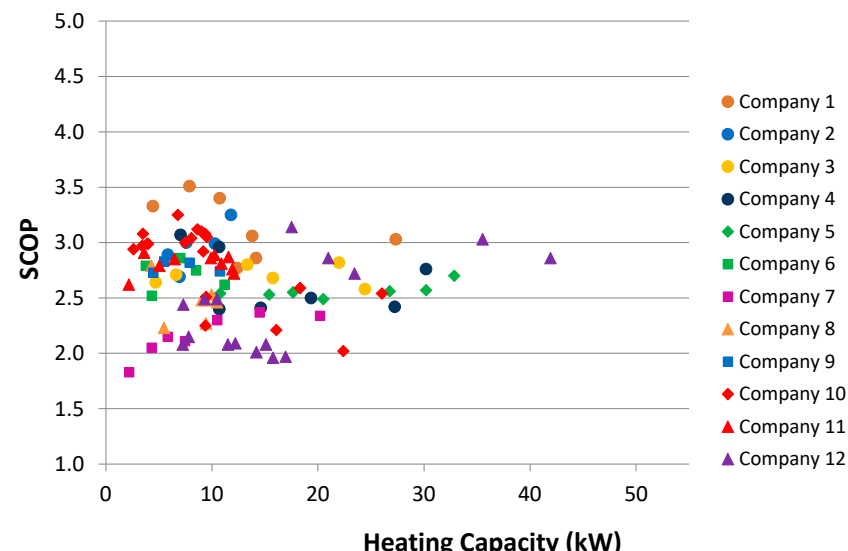

(d)

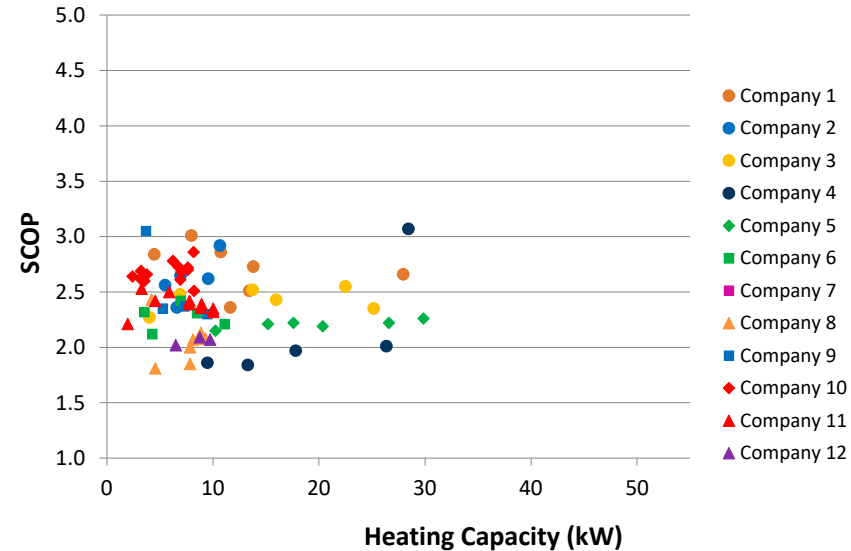

$(\mathbf{f})$

Figure 6. SCOP against HP's heating capacity for the city of Florina: (a) $\mathrm{T}_{\mathrm{w} \text {,outlet }}=35^{\circ} \mathrm{C}$-without compensation, (b) $\mathrm{T}_{\mathrm{w} \text {,outlet }}=35^{\circ} \mathrm{C}$-with compensation, (c) $\mathrm{T}_{\mathrm{w} \text {,outlet }}=45^{\circ} \mathrm{C}$-without compensation, (d) $\mathrm{T}_{\mathrm{w} \text {, outlet }}=45^{\circ} \mathrm{C}$-with compensation, (e) $\mathrm{T}_{\mathrm{w} \text {,outlet }}=55^{\circ} \mathrm{C}$-without compensation, (f) $\mathrm{T}_{\mathrm{w} \text {,outlet }}=55^{\circ} \mathrm{C}$-with compensation.

Concerning Climatic Zone B (Athens) the values of SCOP, as shown in Figure 4, range from 1.64 to 4.64 . For HPs with heating capacity up to $20 \mathrm{~kW}$, the SCOP ranges from 2.6 to 4.64, from 2.1 to 4.02 , and from 1.7 to 3.49 for $\mathrm{T}_{\mathrm{w} \text {,outlet }} 35,45$, and $55^{\circ} \mathrm{C}$, respectively, while for HPs with heating capacity from 20 up to $50 \mathrm{~kW}$, the SCOP values range from 2.52 to 4.15 , from 2.08 to 3.62 , and from 1.64 to 3.17 for $\mathrm{T}_{\mathrm{w}, \text { outlet }} 35,45$, and $55^{\circ} \mathrm{C}$, respectively. It is observed that the maximum values of SCOP are higher in the city of Athens than those in Ierapetra, although the climate in Ierapetra is clearly milder. As mentioned Section 2, this paradox in the case of Ierapetra is due to the particularly high number of hours, in which the outdoor air temperature is lower than the $\mathrm{T}_{\text {des }}$, which causes the operation of the HP for a much longer period (compared to the case of Athens) with electrical heaters, causing a reduction in its seasonal efficiency. According to the conclusions of [21], in the case of Ierapetra, the HPs should be selected with a heating capacity corresponding to a temperature lower than $\mathrm{T}_{\mathrm{des}}$ in order to increase the number of operating hours of the HP and to reduce the operation of the electrical heaters (the same applies to all regions whose climate has these characteristics).

In the case of Thessaloniki (Climate Zone C), the values of SCOP, as displayed in Figure 5, range from 1.55 to 4.52 depending on the water supply temperature to the heating system, the control system, and the compressor technology. In the case of HPs with heating capacity up to $20 \mathrm{~kW}$, the SCOP ranges from 2.40 to 4.52 , from 1.96 to 3.93 , and from 1.55 to 3.34 for water supply temperatures of 35,45 , and $55^{\circ} \mathrm{C}$, respectively. The ranges of SCOP 
for HPs with heating capacity from 20 to $50 \mathrm{~kW}$ are from 2.39 to 3.93 , from 1.97 to 3.44 , and from 1.72 to 3.04 for water supply temperatures of 35,45 , and $55^{\circ} \mathrm{C}$, respectively.

Finally, in the case of Florina (Climate Zone D), the SCOP values, as presented in Figure 6, range from 1.38 to 4.03 . More specifically, HPs with heating capacity up to $20 \mathrm{~kW}$ show SCOP values that range from 2.07 to 4.03 , from 1.67 to 3.51 , and from 1.38 to 3.05 for Tw,outlet 35,45 and $55{ }^{\circ} \mathrm{C}$, respectively. The ranges of SCOP for HPs with heating capacity from 20 to $50 \mathrm{~kW}$ are from 2.41 to 3.53, from 1.82 to 3.03, and from 1.55 to 3.07 for Tw,outlet 35,45 , and $55^{\circ} \mathrm{C}$, respectively.

The results, in the climatic conditions of all four cities, show that the AWHPs with heating capacity up to $20 \mathrm{~kW}$ have a wider range of SCOP values as well as higher maximum values in relation to the AWHPs with heating capacities from 20 to $50 \mathrm{~kW}$. This is particularly important because, in nZEBs or apartments with very low heat loads, highly efficient AWHPs may be installed after a proper market research.

Table 3 shows the range and the average of SCOP values, in relation to three parameters, the $T_{w, o u t l e t}\left(35,45\right.$, or $\left.55{ }^{\circ} \mathrm{C}\right)$, the control system (with compensation or without compensation), and the HPs compressor technology (fixed capacity or inverter-driven). As can be seen from the table values, the HPs with a variable speed compressor (inverterdriven) show an increased average SCOP value by $11 \%, 18 \%, 16 \%$, and $11 \%$ in Ierapetra, Athens, Thessaloniki, and Florina, respectively, compared with the corresponding SCOP of HPs with a fixed-capacity compressor. Additionally, these values appear even higher $(12 \%, 21 \%, 18 \%$, and $13 \%$, respectively) with a water compensation control system. Of course, as mentioned in the previous section, the calculation of SCOP was based on the assumption that the design load of the building in each case study is equal to the maximum heating capacity of the HP. If the HPs with a fixed-capacity compressor were selected with a heating capacity less than the design load of the building, the SCOP values in the four cities could be increased by up to $4 \%$ according to [21]. It is a subject of future research to show if this also applies to other locations in Greece.

Table 3. Seasonal coefficient of performance range (SCOP) of fixed-capacity and inverter-driven HPs.

\begin{tabular}{|c|c|c|c|c|c|c|c|c|c|c|}
\hline \multirow{2}{*}{ Compressor } & \multirow{2}{*}{$\begin{array}{l}\text { HP Water Outlet } \\
\text { Temperature }\end{array}$} & \multirow{2}{*}{$\begin{array}{l}\text { Control } \\
\text { System * }\end{array}$} & \multicolumn{2}{|c|}{ Ierapetra } & \multicolumn{2}{|c|}{ Athens } & \multicolumn{2}{|c|}{ Thessaloniki } & \multicolumn{2}{|c|}{ Florina } \\
\hline & & & $\operatorname{Min} \div \operatorname{Max}$ & Mean & $\operatorname{Min} \div \operatorname{Max}$ & Mean & $\operatorname{Min} \div \operatorname{Max}$ & Mean & $\operatorname{Min} \div \operatorname{Max}$ & Mean \\
\hline \multirow{6}{*}{$\begin{array}{l}\text { FIXED } \\
\text { CAPAC- } \\
\text { ITY }\end{array}$} & \multirow{2}{*}{$35^{\circ} \mathrm{C}$} & N.Comp. & $2.62 \div 3.63$ & 3.16 & $2.52 \div 3.68$ & 3.12 & $2.39 \div 3.49$ & 2.99 & $2.07 \div 3.26$ & 2.77 \\
\hline & & W.Comp. & $2.67 \div 3.71$ & 3.22 & $2.61 \div 3.88$ & 3.24 & $2.48 \div 3.67$ & 3.12 & $2.11 \div 3.39$ & 2.88 \\
\hline & \multirow{2}{*}{$45^{\circ} \mathrm{C}$} & N.Comp. & $2.17 \div 2.92$ & 2.59 & $2.07 \div 2.86$ & 2.49 & $1.96 \div 2.77$ & 2.37 & $1.67 \div 2.60$ & 2.21 \\
\hline & & W.Comp. & $2.35 \div 3.14$ & 2.80 & $2.34 \div 3.34$ & 2.83 & $2.23 \div 3.21$ & 2.73 & $1.83 \div 2.91$ & 2.50 \\
\hline & \multirow{2}{*}{$55^{\circ} \mathrm{C}$} & N.Comp. & $1.77 \div 2.40$ & 2.19 & $1.64 \div 2.33$ & 2.09 & $1.55 \div 2.29$ & 2.01 & $1.38 \div 2.65$ & 1.90 \\
\hline & & W.Comp. & $2.11 \div 2.68$ & 2.47 & $2.20 \div 2.77$ & 2.56 & $2.11 \div 2.77$ & 2.49 & $1.84 \div 3.07$ & 2.33 \\
\hline \multirow{6}{*}{$\begin{array}{l}\text { INVERTER } \\
\text { DRIVEN }\end{array}$} & \multirow{2}{*}{$35^{\circ} \mathrm{C}$} & N.Comp. & $3.24 \div 4.03$ & 3.54 & $3.30 \div 4.30$ & 3.74 & $2.95 \div 4.15$ & 3.53 & $2.48 \div 3.72$ & 3.10 \\
\hline & & W.Comp. & $3.26 \div 4.20$ & 3.66 & $3.40 \div 4.64$ & 3.98 & $3.07 \div 4.52$ & 3.77 & $2.58 \div 4.03$ & 3.30 \\
\hline & \multirow{2}{*}{$45^{\circ} \mathrm{C}$} & N.Comp. & $2.53 \div 3.22$ & 2.87 & $2.58 \div 3.35$ & 2.95 & $2.37 \div 3.22$ & 2.79 & $2.00 \div 2.89$ & 2.49 \\
\hline & & W.Comp. & $2.87 \div 3.58$ & 3.16 & $2.96 \div 4.02$ & 3.47 & $2.70 \div 3.93$ & 3.28 & $2.23 \div 3.51$ & 2.90 \\
\hline & \multirow{2}{*}{$55^{\circ} \mathrm{C}$} & N.Comp. & $2.10 \div 2.65$ & 2.41 & $1.97 \div 2.71$ & 2.41 & $1.84 \div 2.60$ & 2.26 & $1.48 \div 2.38$ & 2.03 \\
\hline & & W.Comp. & $2.42 \div 2.97$ & 2.71 & $2.49 \div 3.49$ & 2.98 & $2.27 \div 3.34$ & 2.84 & $1.81 \div 3.01$ & 2.50 \\
\hline
\end{tabular}

* Control system: N.Comp. (no compensation), W.Comp. (with compensation). 
In Tables 4-7, the range of SCOP values for each company for the four cities under study and for $\mathrm{T}_{\mathrm{w} \text {,outlet }} 35,45$, and $55^{\circ} \mathrm{C}$ is presented. If the SCOP $\geq 3.0$ condition is set as a criterion for the economic operation of the HP and for its characterization as RES, then, based on the results of the present work, the following emerges:

(a) In the case of Ierapetra (Table 4) and for $\mathrm{T}_{\mathrm{w} \text {,outlet }}=35^{\circ} \mathrm{C}$, most of the models of the sample offered from all the 12 companies show SCOP $\geq 3.0$ (86 models without compensation and 90 with compensation control system). For $\mathrm{T}_{\mathrm{w} \text {,outlet }}=45^{\circ} \mathrm{C}$, the corresponding number of models that have SCOP $\geq 3.0$ decreases significantly (only 7 models without compensation and 49 models with compensation control system offered from 4 and 9 of the 12 companies, respectively). It is worth mentioned that for $\mathrm{T}_{\mathrm{w} \text {,outlet }}=55^{\circ} \mathrm{C}$, none of the HPs of the sample have SCOP $\geq 3.0$.

(b) In the case of Athens (Table 5), when $\mathrm{T}_{\mathrm{w} \text {,outlet }}=35^{\circ} \mathrm{C}$, the number of models that meet the SCOP $\geq 3$ condition is also significant ( 81 models without compensation and 87 models with compensation control system from all 12 companies). When $\mathrm{T}_{\mathrm{w} \text {,outlet }}=45^{\circ} \mathrm{C}$, the corresponding number decreases, as it also significantly decreases in the Climatic Zone A (19 models without compensation and 55 models with compensation control system from 5 and 11 of the 12 companies, respectively). Additionally, for constant $\mathrm{T}_{\mathrm{w} \text {,outlet }}=55^{\circ} \mathrm{C}$, none of the AWHPs have SCOP $\geq 3.0$, while the criterion is fulfilled by 19 models with a compensation control system from three companies.

(c) In the case of Thessaloniki (Table 6), the number of HPs with SCOP $\geq 3$ is reduced even more, especially when the water supply temperature to the heating system is $45^{\circ} \mathrm{C}$. More specifically, for $\mathrm{T}_{\mathrm{w} \text {,outlet }}=35^{\circ} \mathrm{C}$, the corresponding number of models is 76 and 81 without and with compensation control system, respectively, from all the 12 companies. When $\mathrm{T}_{\mathrm{w} \text {,outlet }}=45^{\circ} \mathrm{C}$, then only four models without compensation and 41 models with compensation control system from two and nine companies, respectively, show SCOP $\geq 3$. Moreover, for constant $\mathrm{T}_{\mathrm{w} \text {,outlet }}=55^{\circ} \mathrm{C}$, none of the AWHPs have SCOP $\geq 3.0$, while the criterion is fulfilled by 16 models with compensation control system from three companies.

(d) Finally, in the case of Florina (Table 7), the number of HPs with SCOP $\geq 3$ is significantly reduced, both for $\mathrm{T}_{\mathrm{w} \text {,outlet }}=35^{\circ} \mathrm{C}(46$ and 56 models without or with compensation control system from 8 and 11 companies, respectively) and for $\mathrm{T}_{\mathrm{w} \text {,outlet }}=45^{\circ} \mathrm{C}$ (16 models with compensation control system from five companies), while for $\mathrm{T}_{\mathrm{w} \text {,outlet }}=55^{\circ} \mathrm{C}$, none of the HPs of the sample show SCOP $\geq 3.0$.

Table 4. AWHPs' SCOP per company: Ierapetra, water outlet temperature 35,45 , and $55{ }^{\circ} \mathrm{C}$.

\begin{tabular}{|c|c|c|c|c|}
\hline \multirow{4}{*}{ Company No. } & \multicolumn{4}{|c|}{ Climatic Zone: A (Ierapetra) } \\
\hline & \multicolumn{2}{|c|}{ Fixed Capacity Compressor } & \multicolumn{2}{|c|}{ Inverter Capacity Compressor } \\
\hline & No Compensation & With Compensation & No Compensation & With Compensation \\
\hline & \multicolumn{4}{|c|}{ Water Outlet Temperature: $35^{\circ} \mathrm{C}$} \\
\hline 1 & - & - & $3.39 \div 4.03$ & $3.49 \div 4.20$ \\
\hline 2 & - & - & $3.24 \div 3.79$ & $3.36 \div 3.96$ \\
\hline 3 & $2.96 \div 3.26$ & $3.01 \div 3.32$ & - & - \\
\hline 4 & $2.91 \div 3.29$ & $2.97 \div 3.37$ & $3.50 \div 3.68$ & $3.60 \div 3.78$ \\
\hline 5 & $3.07 \div 3.34$ & $3.12 \div 3.40$ & - & - \\
\hline 6 & $3.29 \div 3.63$ & $3.36 \div 3.71$ & - & - \\
\hline 7 & $2.97 \div 3.13$ & $3.03 \div 3.20$ & - & - \\
\hline 8 & - & - & $3.40 \div 3.71$ & $3.44 \div 3.78$ \\
\hline 9 & $3.22 \div 3.43$ & $3.40 \div 3.50$ & - & - \\
\hline 10 & $2.91 \div 3.16$ & $2.95 \div 3.21$ & $3.33 \div 3.71$ & $3.45 \div 3.90$ \\
\hline 11 & $3.15 \div 3.52$ & $3.21 \div 3.58$ & - & - \\
\hline 12 & $2.62 \div 2.77$ & $2.67 \div 2.82$ & $3.26 \div 3.73$ & $3.37 \div 3.89$ \\
\hline
\end{tabular}


Table 4. Cont.

\section{Climatic Zone: A (Ierapetra)}

\begin{tabular}{|c|c|c|c|c|}
\hline \multirow{3}{*}{ Company No. } & \multicolumn{2}{|c|}{ Fixed Capacity Compressor } & \multicolumn{2}{|c|}{ Inverter Capacity Compressor } \\
\hline & No Compensation & With Compensation & No Compensation & With Compensation \\
\hline & \multicolumn{4}{|c|}{ Water Outlet Temperature: $35^{\circ} \mathrm{C}$} \\
\hline & \multicolumn{4}{|c|}{ Water Outlet Temperature: $45^{\circ} \mathrm{C}$} \\
\hline 1 & - & - & $2.78 \div 3.22$ & $3.03 \div 3.58$ \\
\hline 2 & - & - & $2.53 \div 3.00$ & $2.89 \div 3.41$ \\
\hline 3 & $2.48 \div 2.73$ & $2.66 \div 2.94$ & - & - \\
\hline 4 & $2.37 \div 2.69$ & $2.56 \div 2.90$ & $2.92 \div 3.02$ & $3.15 \div 3.25$ \\
\hline 5 & $2.59 \div 2.75$ & $2.74 \div 2.96$ & - & - \\
\hline 6 & $2.64 \div 2.85$ & $2.90 \div 3.14$ & - & - \\
\hline 7 & $2.41 \div 2.64$ & $2.62 \div 2.75$ & - & - \\
\hline 8 & - & - & $2.76 \div 3.04$ & $3.01 \div 3.26$ \\
\hline 9 & $2.62 \div 2.75$ & $2.92 \div 3.01$ & - & - \\
\hline 10 & $2.54 \div 2.66$ & $2.69 \div 2.83$ & $2.71 \div 3.06$ & $3.11 \div 3.34$ \\
\hline 11 & $2.54 \div 2.92$ & $2.73 \div 3.14$ & - & - \\
\hline \multirow[t]{2}{*}{12} & $2.17 \div 2.31$ & $2.35 \div 2.47$ & $2.63 \div 2.89$ & $2.87 \div 3.25$ \\
\hline & \multicolumn{4}{|c|}{ Water Outlet Temperature: $55^{\circ} \mathrm{C}$} \\
\hline 1 & - & - & $2.26 \div 2.56$ & $2.59 \div 2.97$ \\
\hline 2 & - & - & $2.27 \div 2.62$ & $2.46 \div 2.87$ \\
\hline 3 & $2.19 \div 2.31$ & $2.37 \div 2.58$ & - & - \\
\hline 4 & $1.77 \div 2.26$ & $2.11 \div 2.52$ & - & - \\
\hline 5 & $2.04 \div 2.12$ & $2.35 \div 2.40$ & - & - \\
\hline 6 & $2.02 \div 2.27$ & $2.36 \div 2.61$ & - & - \\
\hline 7 & - & - & - & - \\
\hline 8 & - & - & $2.30 \div 2.44$ & $2.58 \div 2.74$ \\
\hline 9 & $2.21 \div 2.33$ & $2.50 \div 2.60$ & - & - \\
\hline 10 & - & - & $2.36 \div 2.65$ & $2.64 \div 2.92$ \\
\hline 11 & $2.10 \div 2.40$ & $2.33 \div 2.68$ & - & - \\
\hline 12 & - & - & $2.10 \div 2.16$ & $2.42 \div 2.50$ \\
\hline
\end{tabular}

Table 5. AWHPs' SCOP per company: Athens, water outlet temperature 35,45 , and $55^{\circ} \mathrm{C}$.

\section{Climatic Zone: B (Athens)}

\begin{tabular}{|c|c|c|c|c|}
\hline \multirow{3}{*}{ Company No. } & \multicolumn{2}{|c|}{ Fixed Capacity Compressor } & \multicolumn{2}{|c|}{ Inverter Capacity Compressor } \\
\hline & No Compensation & With Compensation & No Compensation & With Compensation \\
\hline & \multicolumn{4}{|c|}{ Water Outlet Temperature: $35^{\circ} \mathrm{C}$} \\
\hline 1 & - & - & $3.40 \div 4.30$ & $3.56 \div 4.64$ \\
\hline 2 & - & - & $3.48 \div 4.18$ & $3.72 \div 4.52$ \\
\hline 3 & $2.96 \div 3.28$ & $3.07 \div 3.40$ & - & - \\
\hline 4 & $2.87 \div 3.29$ & $2.98 \div 3.44$ & $3.69 \div 3.79$ & $3.88 \div 3.97$ \\
\hline 5 & $3.05 \div 3.34$ & $3.15 \div 3.46$ & - & - \\
\hline 6 & $3.22 \div 3.68$ & $3.34 \div 3.88$ & - & - \\
\hline 7 & $2.85 \div 3.16$ & $2.95 \div 3.29$ & - & - \\
\hline 8 & - & - & $3.33 \div 3.69$ & $3.40 \div 3.83$ \\
\hline 9 & $3.15 \div 3.45$ & $3.47 \div 3.60$ & - & - \\
\hline 10 & $2.75 \div 3.05$ & $2.82 \div 3.14$ & $3.70 \div 4.08$ & $3.98 \div 4.41$ \\
\hline 11 & $3.16 \div 3.55$ & $3.28 \div 3.67$ & - & - \\
\hline 12 & $2.52 \div 2.72$ & $2.61 \div 2.82$ & $3.30 \div 4.02$ & $3.44 \div 4.33$ \\
\hline
\end{tabular}


Table 5. Cont.

\section{Climatic Zone: B (Athens)}

\begin{tabular}{|c|c|c|c|c|}
\hline \multirow{3}{*}{ Company No. } & \multicolumn{2}{|c|}{ Fixed Capacity Compressor } & \multicolumn{2}{|c|}{ Inverter Capacity Compressor } \\
\hline & No Compensation & With Compensation & No Compensation & With Compensation \\
\hline & \multicolumn{4}{|c|}{ Water Outlet Temperature: $35^{\circ} \mathrm{C}$} \\
\hline & \multicolumn{4}{|c|}{ Water Outlet Temperature: $45^{\circ} \mathrm{C}$} \\
\hline 1 & - & - & $2.74 \div 3.35$ & $3.13 \div 4.02$ \\
\hline 2 & - & - & $2.65 \div 3.12$ & $3.22 \div 3.87$ \\
\hline 3 & $2.47 \div 2.71$ & $2.78 \div 3.06$ & - & - \\
\hline 4 & $2.27 \div 2.62$ & $2.61 \div 3.00$ & $2.93 \div 3.06$ & $3.35 \div 3.46$ \\
\hline 5 & $2.50 \div 2.69$ & $2.78 \div 3.04$ & - & - \\
\hline 6 & $2.52 \div 2.78$ & $2.91 \div 3.34$ & - & - \\
\hline 7 & $2.24 \div 2.51$ & $2.56 \div 2.74$ & - & - \\
\hline 8 & - & - & $2.66 \div 2.93$ & $3.00 \div 3.31$ \\
\hline 9 & $2.49 \div 2.70$ & $3.02 \div 3.12$ & - & - \\
\hline 10 & $2.33 \div 2.49$ & $2.54 \div 2.78$ & $2.90 \div 3.28$ & $3.53 \div 3.88$ \\
\hline 11 & $2.46 \div 2.86$ & $2.79 \div 3.20$ & - & - \\
\hline \multirow[t]{2}{*}{12} & $2.07 \div 2.19$ & $2.34 \div 2.46$ & $2.58 \div 3.01$ & $2.96 \div 3.69$ \\
\hline & \multicolumn{4}{|c|}{ Water Outlet Temperature: $55^{\circ} \mathrm{C}$} \\
\hline 1 & - & - & $2.16 \div 2.68$ & $2.72 \div 3.39$ \\
\hline 2 & - & - & $2.19 \div 2.64$ & $2.71 \div 3.23$ \\
\hline 3 & $2.12 \div 2.26$ & $2.46 \div 2.70$ & - & - \\
\hline 4 & $1.64 \div 2.16$ & $2.2 \div 2.61$ & - & - \\
\hline 5 & $1.93 \div 2.03$ & $2.44 \div 2.50$ & - & - \\
\hline 6 & $1.86 \div 2.16$ & $2.48 \div 2.75$ & - & - \\
\hline 7 & - & - & - & - \\
\hline 8 & - & - & $2.14 \div 2.28$ & $2.56 \div 2.79$ \\
\hline 9 & $2.12 \div 2.22$ & $2.62 \div 2.69$ & - & - \\
\hline 10 & - & - & $2.42 \div 2.71$ & $3.04 \div 3.49$ \\
\hline 11 & $2.01 \div 2.33$ & $2.37 \div 2.77$ & - & - \\
\hline 12 & - & - & $1.97 \div 2.01$ & $2.49 \div 2.57$ \\
\hline
\end{tabular}

Table 6. AWHPs' SCOP per company: Thessaloniki, water outlet temperature 35,45 , and $55{ }^{\circ} \mathrm{C}$.

\section{Climatic Zone: C (Thessaloniki)}

\begin{tabular}{|c|c|c|c|c|}
\hline \multirow{4}{*}{ Company No. } & \multicolumn{4}{|c|}{ Climatic Zone: C (Thessaloniki) } \\
\hline & \multicolumn{2}{|c|}{ Fixed Capacity Compressor } & \multicolumn{2}{|c|}{ Inverter Capacity Compressor } \\
\hline & No Compensation & With Compensation & No Compensation & With Compensation \\
\hline & \multicolumn{4}{|c|}{ Water Outlet Temperature: $35^{\circ} \mathrm{C}$} \\
\hline 1 & - & - & $3.27 \div 4.15$ & $3.43 \div 4.52$ \\
\hline 2 & - & - & $3.28 \div 3.91$ & $3.51 \div 4.22$ \\
\hline 3 & $2.88 \div 3.18$ & $2.99 \div 3.30$ & - & - \\
\hline 4 & $2.77 \div 3.17$ & $2.89 \div 3.31$ & $3.58 \div 3.67$ & $3.78 \div 3.87$ \\
\hline 5 & $2.94 \div 3.20$ & $3.05 \div 3.33$ & - & - \\
\hline 6 & $3.09 \div 3.49$ & $3.24 \div 3.67$ & - & - \\
\hline 7 & $2.6 \div 3.07$ & $2.68 \div 3.20$ & - & - \\
\hline 8 & - & - & $2.95 \div 3.31$ & $3.07 \div 3.45$ \\
\hline 9 & $3.04 \div 3.34$ & $3.36 \div 3.49$ & - & - \\
\hline 10 & $2.60 \div 2.96$ & $2.68 \div 3.06$ & $3.48 \div 3.89$ & $3.73 \div 4.14$ \\
\hline 11 & $3.13 \div 3.46$ & $3.26 \div 3.59$ & - & - \\
\hline 12 & $2.39 \div 2.63$ & $2.48 \div 2.74$ & $3.09 \div 3.80$ & $3.26 \div 4.09$ \\
\hline
\end{tabular}


Table 6. Cont.

\begin{tabular}{|c|c|c|c|c|}
\hline \multirow{4}{*}{ Company No. } & \multicolumn{4}{|c|}{ Climatic Zone: C (Thessaloniki) } \\
\hline & \multicolumn{2}{|c|}{ Fixed Capacity Compressor } & \multicolumn{2}{|c|}{ Inverter Capacity Compressor } \\
\hline & No Compensation & With Compensation & No Compensation & With Compensation \\
\hline & \multicolumn{4}{|c|}{ Water Outlet Temperature: $35^{\circ} \mathrm{C}$} \\
\hline & \multicolumn{4}{|c|}{ Water Outlet Temperature: $45^{\circ} \mathrm{C}$} \\
\hline 1 & - & - & $2.60 \div 3.22$ & $3.01 \div 3.93$ \\
\hline 2 & - & - & $2.52 \div 2.99$ & $3.04 \div 3.68$ \\
\hline 3 & $2.42 \div 2.66$ & $2.73 \div 3.00$ & - & - \\
\hline 4 & $2.15 \div 2.54$ & $2.55 \div 2.92$ & $2.82 \div 2.95$ & $3.25 \div 3.38$ \\
\hline 5 & $2.40 \div 2.58$ & $2.70 \div 2.94$ & - & - \\
\hline 6 & $2.30 \div 2.69$ & $2.82 \div 3.21$ & - & - \\
\hline 7 & $2.06 \div 2.33$ & $2.38 \div 2.62$ & - & - \\
\hline 8 & - & - & $2.37 \div 2.67$ & $2.70 \div 3.04$ \\
\hline 9 & $2.39 \div 2.61$ & $2.94 \div 3.04$ & - & - \\
\hline 10 & $2.15 \div 2.42$ & $2.36 \div 2.73$ & $2.77 \div 3.14$ & $2.98 \div 3.66$ \\
\hline 11 & $2.41 \div 2.77$ & $2.78 \div 3.13$ & - & - \\
\hline \multirow[t]{2}{*}{12} & $1.96 \div 2.08$ & $2.23 \div 2.40$ & $2.41 \div 2.91$ & $2.82 \div 3.56$ \\
\hline & \multicolumn{4}{|c|}{ Water Outlet Temperature: $55^{\circ} \mathrm{C}$} \\
\hline 1 & - & - & $2.04 \div 2.60$ & $2.60 \div 3.34$ \\
\hline 2 & - & - & $2.03 \div 2.48$ & $2.59 \div 3.15$ \\
\hline 3 & $2.05 \div 2.22$ & $2.40 \div 2.68$ & - & - \\
\hline 4 & $1.55 \div 2.08$ & $2.11 \div 2.54$ & - & - \\
\hline 5 & $1.84 \div 1.96$ & $2.37 \div 2.44$ & - & - \\
\hline 6 & $1.76 \div 2.05$ & $2.41 \div 2.67$ & - & - \\
\hline 7 & - & - & - & - \\
\hline 8 & - & - & $1.86 \div 2.14$ & $2.27 \div 2.61$ \\
\hline 9 & $2.04 \div 2.18$ & $2.57 \div 2.77$ & - & - \\
\hline 10 & - & - & $2.34 \div 2.56$ & $2.84 \div 3.24$ \\
\hline 11 & $1.98 \div 2.29$ & $2.35 \div 2.71$ & - & - \\
\hline 12 & - & - & $1.84 \div 1.88$ & $2.36 \div 2.41$ \\
\hline
\end{tabular}

Summarizing the above, it seems that, in all four representative cities of Climatic Zones $\mathrm{A}, \mathrm{B}, \mathrm{C}$, and D, there are several HP models that accomplish the criterion SCOP $\geq 3$. This number increases as we go from colder to warmer climate conditions in combination with lower water supply temperature to the heating system and operation with compensation instead of constant water temperature.

Table 8 shows the percentage increase in SCOP values resulting from the application of the temperature compensation function as well as from the reduction of the water supply temperature $\mathrm{T}_{\mathrm{w}, \text { outlet }}$ from 45 to $35^{\circ} \mathrm{C}$ and from 55 to $45^{\circ} \mathrm{C}$. More specifically, the temperature compensation increases the efficiency of the fixed-capacity HPs by $2 \div 4.2 \%$ ( 0.06 to 0.13 in absolute values), by $7.8 \div 14.9 \%$ ( 0.21 to 0.36 in absolute values), and by $12.7 \div 23.8 \%$ ( 0.28 to 0.48 in absolute values) for $\mathrm{T}_{\mathrm{w} \text {,outlet }} 35,45$, and $55^{\circ} \mathrm{C}$, respectively, while in the case of HPs with an inverter-driven compressor, the corresponding increase is $3.5 \div 6.8 \%$ ( 0.12 to 0.24 in absolute terms), $10.1 \div 17.7 \%$ ( 0.29 to 0.49 in absolute terms), and $12.5 \div 25.4 \%$ ( 0.30 to 0.58 in absolute terms).

In addition, in the case of fixed-capacity HPs, by reducing the $\mathrm{T}_{\mathrm{w}, \text { outlet }}$ from 45 to $35{ }^{\circ} \mathrm{C}$, the value of SCOP increases by $21.8 \div 25.9 \%$ ( 0.57 to 0.62 in absolute values) in systems without temperature compensation and by $14.3 \div 15.3 \%$ ( 0.39 to 0.42 in absolute terms) when temperature compensation is applied. In the case of inverter-driven HPs, the reduction of the $\mathrm{T}_{\mathrm{w}, \text { outlet }}$ from 45 to $35{ }^{\circ} \mathrm{C}$ causes a corresponding increase of the SCOP value by $23.3 \div 26.9 \%$ ( 0.67 to 0.79 in absolute values) and by $14 \div 16.1 \%$ ( 0.40 to 0.50 in absolute terms). Finally, in the case of fixed-capacity HPs, by reducing the $\mathrm{T}_{\mathrm{w}, \text { outlet }}$ from 55 to $45^{\circ} \mathrm{C}$, the value of SCOP increases by $16.0 \div 18.9 \%$ ( 0.30 to 0.40 in absolute values) and by $7.3 \div 13.2 \%$ ( 0.17 to 0.33 in absolute terms) in systems without and with compensation 
control system, respectively, while in the case of inverter-driven HPs, this reduction of the water supply temperature causes a corresponding increase of the SCOP value by $19.2 \div$ $23.4 \%$ ( 0.46 to 0.53 in absolute values) and by $15.6 \div 16.6 \%$ ( 0.44 to 0.49 in absolute terms).

Table 7. AWHPs' SCOP per company: Florina, water outlet temperature 35,45 , and $55{ }^{\circ} \mathrm{C}$.

\begin{tabular}{|c|c|c|c|c|}
\hline \multirow{4}{*}{ Company No. } & \multicolumn{4}{|c|}{ Climatic Zone: D (Florina) } \\
\hline & \multicolumn{2}{|c|}{ Fixed Capacity Compressor } & \multicolumn{2}{|c|}{ Inverter Capacity Compressor } \\
\hline & No Compensation & With Compensation & No Compensation & With Compensation \\
\hline & \multicolumn{4}{|c|}{ Water Outlet Temperature: $35^{\circ} \mathrm{C}$} \\
\hline 1 & - & - & $3.06 \div 3.72$ & $3.21 \div 4.03$ \\
\hline 2 & - & - & $2.88 \div 3.42$ & $3.09 \div 3.66$ \\
\hline 3 & $2.73 \div 2.99$ & $2.81 \div 3.09$ & - & - \\
\hline 4 & $2.65 \div 3.02$ & $2.76 \div 3.14$ & $3.28 \div 3.40$ & $3.45 \div 3.56$ \\
\hline 5 & $2.74 \div 2.95$ & $2.83 \div 3.05$ & - & - \\
\hline 6 & $2.8 \div 3.13$ & $2.92 \div 3.27$ & - & - \\
\hline 7 & $2.07 \div 2.86$ & $2.11 \div 2.97$ & - & - \\
\hline 8 & - & - & $2.48 \div 2.94$ & $2.58 \div 3.04$ \\
\hline 9 & $2.86 \div 3.10$ & $3.10 \div 3.24$ & - & - \\
\hline 10 & $2.41 \div 2.79$ & $2.49 \div 2.88$ & $3.02 \div 3.49$ & $3.19 \div 3.74$ \\
\hline 11 & $2.99 \div 3.26$ & $3.12 \div 3.39$ & - & - \\
\hline \multirow[t]{2}{*}{12} & $2.13 \div 2.46$ & $2.20 \div 2.55$ & $2.69 \div 3.39$ & $2.83 \div 3.62$ \\
\hline & \multicolumn{4}{|c|}{ Water Outlet Temperature: $45^{\circ} \mathrm{C}$} \\
\hline 1 & - & - & $2.41 \div 2.89$ & $2.77 \div 3.51$ \\
\hline 2 & - & - & $2.25 \div 2.76$ & $2.69 \div 3.25$ \\
\hline 3 & $2.33 \div 2.55$ & $2.58 \div 2.82$ & - & - \\
\hline 4 & $1.98 \div 2.42$ & $2.40 \div 2.76$ & $2.59 \div 2.70$ & $2.96 \div 3.07$ \\
\hline 5 & $2.23 \div 2.40$ & $2.49 \div 2.70$ & - & - \\
\hline 6 & $2.18 \div 2.49$ & $2.52 \div 2.86$ & - & - \\
\hline 7 & $1.67 \div 2.09$ & $1.83 \div 2.37$ & - & - \\
\hline 8 & - & - & $2.00 \div 2.53$ & $2.23 \div 2.79$ \\
\hline 9 & $2.25 \div 2.46$ & $2.73 \div 2.83$ & - & - \\
\hline 10 & $1.82 \div 2.31$ & $2.02 \div 2.59$ & $2.47 \div 2.81$ & $2.92 \div 3.25$ \\
\hline 11 & $2.28 \div 2.60$ & $2.62 \div 2.91$ & - & - \\
\hline \multirow[t]{2}{*}{12} & $1.75 \div 1.88$ & $1.96 \div 2.15$ & $2.13 \div 2.65$ & $2.44 \div 3.14$ \\
\hline & \multicolumn{4}{|c|}{ Water Outlet Temperature: $55^{\circ} \mathrm{C}$} \\
\hline 1 & - & - & $1.87 \div 2.38$ & $2.36 \div 3.01$ \\
\hline 2 & - & - & $1.90 \div 2.32$ & $2.36 \div 2.92$ \\
\hline 3 & $1.96 \div 2.13$ & $2.27 \div 2.55$ & - & - \\
\hline 4 & $1.38 \div 1.92$ & $1.84 \div 3.07$ & - & - \\
\hline 5 & $1.70 \div 1.85$ & $2.15 \div 2.26$ & - & - \\
\hline 6 & $1.59 \div 1.85$ & $2.12 \div 2.42$ & - & - \\
\hline 7 & - & - & - & - \\
\hline 8 & - & - & $1.48 \div 2.01$ & $1.81 \div 2.43$ \\
\hline 9 & $1.90 \div 2.65$ & $2.30 \div 3.05$ & - & - \\
\hline 10 & - & - & $2.11 \div 2.27$ & $2.51 \div 2.86$ \\
\hline 11 & $1.89 \div 2.17$ & $2.21 \div 2.53$ & - & - \\
\hline 12 & - & - & $1.56 \div 1.65$ & $2.02 \div 2.09$ \\
\hline
\end{tabular}


Table 8. Seasonal coefficient of performance (SCOP) increase due to decrease of the water outlet temperature (from 45 to $35{ }^{\circ} \mathrm{C}$ and from 55 to $45^{\circ} \mathrm{C}$ ) and weather compensation.

\begin{tabular}{|c|c|c|c|c|c|c|c|}
\hline & \multicolumn{7}{|c|}{ Fixed-Capacity Compressor } \\
\hline & \multicolumn{3}{|c|}{ From N.Comp. to W.Comp. } & \multicolumn{2}{|c|}{ From 45 to $35^{\circ} \mathrm{C}$} & \multicolumn{2}{|c|}{ From 55 to $45^{\circ} \mathrm{C}$} \\
\hline & $35^{\circ} \mathrm{C}$ & $45^{\circ} \mathrm{C}$ & $55^{\circ} \mathrm{C}$ & N.C. & W.C. & N.C. & W.C. \\
\hline Ierapetra & $2.0 \%$ & $7.8 \%$ & $12.7 \%$ & $21.8 \%$ & $15.3 \%$ & $18.4 \%$ & $13.2 \%$ \\
\hline Athens & $3.9 \%$ & $13.7 \%$ & $22.4 \%$ & $25.4 \%$ & $14.6 \%$ & $18.9 \%$ & $10.4 \%$ \\
\hline Thassaloniki & $4.2 \%$ & $14.9 \%$ & $23.8 \%$ & $25.9 \%$ & $14.3 \%$ & $17.9 \%$ & $9.4 \%$ \\
\hline \multirow[t]{4}{*}{ Florina } & $4.0 \%$ & $13.3 \%$ & $22.6 \%$ & $25.7 \%$ & $15.3 \%$ & $16.0 \%$ & $7.3 \%$ \\
\hline & \multicolumn{7}{|c|}{ Inverter-Driven Compressor } \\
\hline & \multicolumn{3}{|c|}{ From N.Comp. to W.Comp. } & \multicolumn{2}{|c|}{ From 45 to $35^{\circ} \mathrm{C}$} & \multicolumn{2}{|c|}{ From 55 to $45^{\circ} \mathrm{C}$} \\
\hline & $35^{\circ} \mathrm{C}$ & $45^{\circ} \mathrm{C}$ & $55^{\circ} \mathrm{C}$ & N.C. & W.C. & N.C. & W.C. \\
\hline Ierapetra & $3.5 \%$ & $10.1 \%$ & $12.5 \%$ & $23.3 \%$ & $16.1 \%$ & $19.2 \%$ & $16.6 \%$ \\
\hline Athens & $6.4 \%$ & $17.7 \%$ & $23.7 \%$ & $26.9 \%$ & $14.8 \%$ & $22.6 \%$ & $16.6 \%$ \\
\hline Thassaloniki & $6.8 \%$ & $17.5 \%$ & $25.4 \%$ & $26.3 \%$ & $14.7 \%$ & $23.4 \%$ & $15.6 \%$ \\
\hline Florina & $6.3 \%$ & $16.1 \%$ & $23.2 \%$ & $24.5 \%$ & $14.0 \%$ & $23.0 \%$ & $15.9 \%$ \\
\hline
\end{tabular}

Control system: N.Comp. (no compensation), W.Comp. (with compensation).

\section{Conclusions}

In this work, an analytic study on the seasonal coefficient of performance (SCOP) of AWHPs, which are available in the Greek market, was performed. The study was based on the technical characteristics of $100 \mathrm{HP}$ models from 12 manufacturing companies. The calculation of SCOP values was conducted according to the EN14825 standard, by taking into account the climatic data of four representative cities, one for each climatic zone of Greece, and considering that the heating capacity at the design temperature in each city is equal to the building thermal load. The variables of the analysis were the HP's heating capacity (from 2 to $50 \mathrm{~kW}$ ), the water supply temperature in the heating system (the cases of 35,45 , and $55^{\circ} \mathrm{C}$ were examined) and the heat supply control system (considered systems with or without weather compensation). The results show that for the climatic data of all four cities, the AWHPs with low heating capacity (up to $20 \mathrm{~kW}$ ) show a wider range of SCOP values as well as higher maximum SCOP values compared to the HPs with heating capacity from 20 to $50 \mathrm{~kW}$. In addition, SCOP is highly dependent on the climatic data of the region. In areas where the outdoor air temperature is lower than the heating design temperature for a large number of hours, it is observed that the operation of the auxiliary energy source (electrical heaters) reduces the seasonal efficiency. In these cases, the selection of a HP with higher heating capacity than the design load must be considered. Two additional factors that significantly affect the HP's seasonal efficiency are the water supply temperature to the heating system as well as the control of the water supply temperature. More specifically, the application of a control system with weather compensation in the operation of the HP increases the seasonal efficiency significantly, especially when the supply temperature is 45 and $55{ }^{\circ} \mathrm{C}$. It is also worth mentioning that by reducing the water temperature from 55 to $35^{\circ} \mathrm{C}$, in combination with the application of the compensation control system, the SCOP increases by $47 \% \div 55 \%$ and $52 \% \div 66 \%$ in the case of fixed-capacity and inverter-driven $\mathrm{HPs}$, respectively. Of the $100 \mathrm{HP}$ models tested in the four representative cities, it was found that there is a large number of HPs showing SCOP $\geq 3$, which is a criterion for the economic operation of a HP but also for its characterization as RES. The number of HPs that meet this criterion increases from the colder to the warmer climates in combination with lower heating water supply temperatures and in systems with variable water supply temperature (compensation control system) instead of constant water supply temperature.

The results confirm that the seasonal efficiency in heating is influenced by many factors, such as the climate of the area, the technology of the compressor, the water supply temperature to the heating system, and the water supply temperature control system, 
which should be taken under consideration in the selection of HPs and in the design of heating systems, in order to achieve the optimal degree of efficiency of the heating system.

Author Contributions: Data curation, formal analysis and software, G.A.M.; methodology validation and writing original draft, G.A.M. and K.T.P.; supervision and validation, review and editing, K.T.P. All authors have read and agreed to the published version of the manuscript.

Funding: This research received no external funding.

Conflicts of Interest: The authors declare no conflict of interest.

\section{References}

1. Eurostat. Energy Data-2020 Edition; Publications Office of the European Union: Luxembourg, 2020; ISBN 9789276206293. [CrossRef]

2. Eurostat. Energy, Transport and Environment Statistics; Publications Office of the European Union: Luxembourg, 2020; ISBN 978-92-76-20736-8. [CrossRef]

3. European Commission. Communication from the Commission to the European Parliament, the Council, the European Economic and Social Committee and the Committee of the Regions Energy Roadmap 2050; European Commission: Brussels, Belgium, 2011.

4. Mouzeviris, G.A.; Papakostas, K.T. Seasonal heat performances of air-to-water heat pumps in the Greek climate. Earth Environ. Sci. 2020, 410, 012043. [CrossRef]

5. Mouzeviris, G.A.; Papakostas, K.T. Comparative Analysis of Air-to-Water and Ground Source Heat Pumps Performances. Int. J. Sustain. Energy 2020, 40, 69-84. [CrossRef]

6. European Union. Directive 2009/28/EC of the European Parliament and of the Council on the promotion of the use of energy from renewable sources and amending and subsequently repealing Directives 2001/77/EC and 2003/30/EC. Off. J. Eur. Union 2009, L 140, 16-62.

7. European Union. Directive 2009/125/EC of the European Parliament and of the Council: Establishing a framework for the setting of eco-design requirements for energy-related products. Off. J. Eur. Union 2009, L 285, 10-35.

8. European Union. Directive 2010/30/EU of the European Parliament and of the Council on the indication by labelling and standard product information of the consumption of energy and other resources by energy-related products. Off. J. Eur. Union 2010, L 153, 1-12.

9. European Union. Directive 2010/31/EU of the European Parliament and of the Council on the energy performance of buildings. Off. J. Eur. Union 2010, L 153, 13-35.

10. European Union. Directive 2012/27/EU of the European Parliament and of the Council, on energy efficiency, amending Directives 2009/125/EC and 2010/30/EU and repealing Directives 2004/8/EC and 2006/32/EC. Off. J. Eur. Union 2012, L 315, 1-56.

11. European Union. Directive (EU) 2018/844 of the European Parliament and of the Council, Amending Directive 2010/31/EU on the energy per-formance of buildings and Directive 2012/27/EU on energy efficiency. Off. J. Eur. Union 2018, L 156, 75-91.

12. Staffell, I.; Brett, D.; Brandon, N.; Hawkes, A. A review of domestic heat pumps. Energy Environ. Sci. 2012, 5, 9291-9306. [CrossRef]

13. Huchtemann, K.; Müller, D. Simulation study on supply temperature optimization in domestic heat pump systems. Build. Environ. 2012, 59, 327-335. [CrossRef]

14. The State of Renewable Energies in Europe; 19th EurObserv'ER Report. 2019. Available online: https://www.isi.fraunhofer.de/ content/dam/isi/dokumente/ccx/2020/The-state-of-renewable-energies-in-Europe-2019.pdf (accessed on 10 April 2021).

15. Madonna, F.; Bazzocchi, F. Annual performances of reversible air-to-water heat pumps in small residential buildings. Energy Build. 2013, 65, 299-309. [CrossRef]

16. Naldi, C.; Dongellini, M.; Morini, G.L. Climate Influence on Seasonal Performances of Air-to-water Heat Pumps for Heating. Energy Procedia 2015, 81, 100-107. [CrossRef]

17. Dongellini, M.; Naldi, C.; Morini, G.L. Seasonal performance evaluation of electric air-to-water heat pump systems. Appl. Therm. Eng. 2015, 90, 1072-1081. [CrossRef]

18. Dongellini, M.; Naldi, C.; Morini, G.L. Sizing effects on the energy performance of reversible air-source heat pumps for office buildings. Appl. Therm. Eng. 2017, 114, 1073-1081. [CrossRef]

19. Dongellini, M.; Morini, G.L. On-off cycling losses of reversible air-to-water heat pump systems as a function of the unit power modulation capacity. Energy Convers. Manag. 2019, 196, 966-978. [CrossRef]

20. Dongellini, M.; Naldi, C.; Morini, G.L. Influence of sizing strategy and control rules on the energy saving potential of heat pump hybrid systems in a residential building. Energy Convers. Manag. 2021, 235, 114022. [CrossRef]

21. Mouzeviris, G.A.; Papakostas, K.T. Air-to-water heat pumps: The impact of climate, compressor technology, water output temperature and sizing on the seasonal coefficient of performance for heating. Mater. Sci. Eng. 2020, 997, 012150. [CrossRef]

22. Wu, P.; Wang, Z.; Li, X.; Xu, Z.; Yang, Y.; Yang, Q. Energy-saving analysis of air source heat pump integrated with a water storage tank for heating applications. Build. Environ. 2020, 180, 107029. [CrossRef]

23. Kudela, L.; Špiláček, M.; Pospíšil, J. Influence of Control Strategy on Seasonal Coefficient of Performance for a Heat Pump with Low-Temperature Heat Storage in the Geographical Conditions of Central Europe. Energy 2021, 234, 121276. [CrossRef] 
24. Pospíšil, J.; Špiláček, M.; Kudela, L. Potential of predictive control for improvement of seasonal coefficient of performance of air source heat pump in Central European climate zone. Energy 2018, 154, 415-423. [CrossRef]

25. Renaldi, R.; Kiprakis, A.; Friedrich, D. An optimization framework for thermal energy storage integration. Appl. Energy 2017, 186, 520-529. [CrossRef]

26. Europen Union. European Standard EN 14825: Air Conditioners, Liquid Chilling Packages and Heat Pumps, with Electrically Driven Compressors, for Space Heating and Cooling-Testing and Rating at Part Load Conditions and Calculation of Seasonal Performance; European Committee for Standardization: Brussels, Belgium, 2018.

27. Carrier. Available online: https:/ / ahi-carrier.gr/product-category/business-solutions/heating/air-to-water-heatpumps / (accessed on 10 December 2020).

28. Climaveneta Technical Bulletin. AWR_MTD2_XE_0011_0091_201211_EN, NECS_N_0202T_0612T_201211_EN, ELCADOC-Ver. 1.0.0.7; De'Longhi: Bassano del Grappa, Italy, 2012.

29. Daikin Altherma. ERHQ-BW1, EEDEN15-725 07/15, ERSQ-AY1; Daikin: Oostende, Belgium, 2017.

30. De Dietrich. Alevisio Evolution, 300019732C, November 2014. Available online: http:/ /www.dedietrich-heating.com/ (accessed on 10 December 2020).

31. Hitachi. Techical Catalogue: RHU-3AVFHN1, RHUE-(3-6)A(V)HN-HM; TCGB0090 rev.0-12/2013; Yutaki, M., Ed.; Hitachi: Tokio, Japan, 2013.

32. LG, Therma V. P/No.: MFL66101110; LG: Seoul, Korea, 2016.

33. Mitsubishi. Ecodan-Air-to-Water Heat Pump Systems, Aug. 2015 M-P0655 SIZ1508; Mitsubishi: Changsha, China, August 2015.

34. Rhoss. K20128EN ed.3, August. 2015. Available online: http://www.rhoss.com/products/applied-systems-en (accessed on 10 December 2020).

35. Stiebel Eltron. Technical Guide: Heat Pumps; Stiebel Eltron: Holzminden, Germany, 2009.

36. Toshiba. Engineering Data Book: Air to Water Heat Pump; Toshiba: Minato, Tokyo, 2017.

37. Trane. Reversible Air-to-Water Scroll Heat Pumps-Model CXA 040-115, Flex Series Heat Pumps; CG-PRC030A-GB 0215; Trane: Dublin, Ireland, 2015.

38. York. Air-Condensed Cooling Units and Heat Pumps YLCA/YLHA 40; User Manual Ref.: N-40314_EN 0912; Johnson Controls: Addison, IL, USA, 2003.

39. Mouzeviris, G.A.; Papakostas, K.T. Comparative Analysis of Air-to-Water Heat Pumps Performances-Seasonal Performance for Heating of Domestic Heat Pumps in the Greek Climate. In Proceedings of the 6th International Conference on Renewable Energy Sources and Energy Efficiency-New Challenges (RESEE2018), Nicosia, Cyprus, 1-2 November 2018; pp. 179-193.

40. Zagana-Papavasileiou, P. Updating of Temperature Data Base of Athens and Thessaloniki for Energy Studies-Period 1983-2012. Diploma Thesis, School of Mechanical Engineering Aristotle University of Thessaloniki, Thessaloniki, Greece, 2013. (In Greek)

41. Kyrou, D. Statistical Analysis of Hourly Ambient Air Dry-Bulb Temperature and Relative Humidity Observations for the Period 1983-2012 in Athens (NOA) -Elaboration of Data for HVAC Energy Analysis Methods. Bachelor's Thesis, School of Mechanical Engineering, Aristotle University of Thessaloniki, Thessaloniki, Greece, 2018. (In Greek)

42. Karadaglis, C.; Felekis, P. Estimation of Bin Temperature Data in 38 Greek Cities. Bachelor's Thesis, School of Mechanical Engineering, Aristotle University Thessaloniki, Thessaloniki, Greece, 2005. (In Greek)

43. Papakostas, K.; Tsilingiridis, G.; Kyriakis, N. Bin weather data for 38 Greek cities. Appl. Energy 2008, 85, 1015-1025. [CrossRef]

44. Technical Directive of the Technical Chamber of Greece T.O.T.E.E. 20701-3/2010 Climatic Data of Greek Regions (In Greek). 2014. Available online: http:/ / portal.tee.gr/portal/page/portal/tptee/totee/TOTEE-20701-3-Final-TEE\%202nd.pdf (accessed on 10 December 2020).

45. Technical Directive of the Technical Chamber of Greece T.O.T.E.E. 20701-1/2017 Analytical Specifications of Parameters for the Calculation of the Energy Performance of Buildings and the Issue of Energy Certificate (In Greek). 2017. Available online: http://portal.tee.gr/portal/page/portal/SCIENTIFIC_WORK/GR_ENERGEIAS/kenak/files/TOTEE_20701-1_2017 _TEE_1st_Edition.pdf (accessed on 10 December 2020). 